\title{
An epilimnion and hypolimnion temperature model based on air temperature and lake characteristics
}

\author{
Jordi Prats $^{1, *}$ and Pierre-Alain Danis ${ }^{2}$ \\ ${ }^{1}$ Irstea, UR RECOVER, Pôle AFB-Irstea Hydroécologie des plans d'eau, 3275 Route de Cézanne, F-13182 Aix-en-Provence Cedex 5, \\ France \\ 2 Agence Française pour la Biodiversité, Pôle AFB-Irstea Hydroécologie des plans d'eau, 3275 Route de Cézanne, F-13182 Aix-en-Provence \\ Cedex 5, France
}

\begin{abstract}
Water temperature is an essential ecological variable that influences life beings at several organizational levels, but its monitoring at the regional level is costly. An alternative is using models, which summarise the knowledge of the functioning of the system so that they can be used to answer specific questions. We present a model to calculate the epilimnion and hypolimnion temperature of inland water bodies based on air temperature and on their geographical and morphological characteristics. The seven model parameters were parameterized by using official monitoring data and the satellite temperature data of the data set LakeSST for French water bodies. The performance of the parameterised model was compared to that of two widely used models (FLake and air2water with four parameters). The model showed a good performance in the simulation of epilimnion temperatures, especially in the summer. For hypolimnion temperatures the performance was worse, but still comparable to that of other models. Because of its good performance and the few data needed to run the model, it is a good choice for managers interested in the thermal behaviour of inland water bodies.
\end{abstract}

Keywords: Epilimnion temperature / France / hypolimnion temperature / inland water body / water temperature modelling

Résumé - Modèle de température de l'épilimnion et l'hypolimnion basée sur la température de l'air et les caractéristiques des lacs. La température de l'eau est une variable écologique essentielle qui influence les êtres vivants à plusieurs niveaux, mais son suivi au niveau régional est coûteux. Une alternative consiste à utiliser des modèles, qui apportent des connaissances sur le fonctionnement des systèmes qui permettent de répondre à des questions spécifiques. Nous présentons ici un modèle pour simuler la température de l'épilimnion et de l'hypolimnion des masses d'eau douce continentales françaises en fonction de la température de l'air et de leurs caractéristiques géographiques et morphologiques. Les sept paramètres du modèle ont été paramétrés à l'aide de données de surveillance règlementaire et des données de température satellitaires LakeSST. La performance du modèle paramétré a été comparée à celle de deux modèles largement utilisés (FLake et air2water avec quatre paramètres). Le modèle est performant pour la simulation des températures de l'épilimnion, surtout en été. Pour les températures de l'hypolimnion, la performance est moins bonne mais toujours comparable à celle des autres modèles. En raison de sa bonne performance et du peu de données nécessaires pour exécuter le modèle, il constitue un bon choix pour les gestionnaires intéressés par connaître le comportement thermique des masses d'eau donce continentales.

Mots-clés: Température de l'épilimnion / France / température de l'hypolimnion / masse d'eau intérieure / modélisation des températures

\footnotetext{
*Corresponding author: jordi.prats@irstea.fr
} 


\section{Introduction}

Water temperature influences life at several organisation levels: metabolism, life cycle, community composition and ecosystem functioning (Daufresne and Boet, 2007; Daufresne et al., 2009). In the last years, the interest in water temperatures has increased because of the effects of climate change (Webb et al., 2008). On the one side, the paper of the interaction of lakes with the climate system, which depends on surface temperature, is increasingly recognised by coupling lake temperature models to climate and meteorological models (MacKay et al., 2009; Subin et al., 2012; Le Moigne et al., 2016). On the other side, a generalised warming of lakes has been observed worldwide (Schneider et al., 2009; Schneider and Hook, 2010; O'Reilly et al., 2015), which results in the intensification and lengthening of summer stratification (Danis et al., 2004; Kraemer et al., 2015; Sahoo et al., 2015) and a reduction of ice cover (Fang and Stefan, 2009; Butcher et al., 2015). These changes in the hydrodynamic and thermal conditions of freshwater bodies favour cyanobacteria and the occurrence of toxic blooms will expectedly increase (Jöhnk et al., 2008; Paerl and Huisman, 2008; Trolle et al., 2011), affecting drinking water uptakes and bathing activities (Falconer, 1999; Ibelings et al., 2014).

However, obtaining long term water temperature data for multiple water bodies in a wide geographical region such as France is costly in terms of personnel and equipment. As a result, the knowledge of the thermodynamic behaviour of French water bodies is limited. Monitoring networks provide data well distributed spatially, but rare in time. Continuous measurements have good resolution in time, but are available on few water bodies only. Individual studies data (e.g. Salençon, 1997) are disperse and sometimes of difficult access. Instead, satellite images offer an interesting way of monitoring lake temperatures; they provide information on surface water temperature on wide spatial and temporal scales at a low cost, so that monitoring can be extended to a great number of non-instrumented water bodies. Thanks to their advantages, satellite images have increasingly been used to study the ecology of lakes in recent years (Dörnhöfer and Oppelt, 2016). Satellite data has been used to study the surface temperatures in extended geographical regions, such as France (Prats et al., 2018a), the Tibetan Plateau (Wan et al., 2017), the Arctic Coastal Plane (Huang et al., 2017), the US (Schaeffer et al., 2018) or even at world scale (Schneider and Hook, 2010; Layden et al., 2015). In other cases, satellite images have been used to study internal thermal patterns in lakes (Marti-Cardona et al., 2008; Allan et al., 2016; Woolway and Merchant, 2018), longitudinal surface thermal gradients in reservoirs (Martí-Cardona et al., 2016; Ling et al., 2017) or how lakes respond to meteorological forcing (Woolway and Merchant, 2017,2018). Since satellites provide historical information starting in the 1980s they have been used to obtain long term data series and analyse the effect of climate change (e.g. Schneider et al., 2009; Schneider and Hook, 2010; Riffler et al., 2015).

However, satellite measurements have some limitations. The periodicity of satellite images is irregular because of clouds or because of operational limits of the number of images taken per day (Goward et al., 2006; Tolnai et al., 2016; Xiao et al., 2018). In addition, satellites retrieve skin temperatures rather than epilimnion or bulk surface temperatures (Schluessel et al., 1990; Donlon et al., 2002). Skin temperature is the temperature that should be used for the calculation of surface fluxes of heat and gas (Kawai and Wada, 2007), but for the biological and management points of view bulk surface temperature is the relevant temperature (Handcock et al., 2012). Depending on the time of the day and meteorological conditions the differences between skin temperature and bulk temperature can amount to a few degrees (Wilson et al., 2013; Prats et al., 2018a).

Nevertheless, models can be used to provide information at relevant spatial and temporal scales at a low cost. They can be used to fill the gaps between measurements, to estimate past temperatures and to make future predictions based on the knowledge of the forcing variables. Several models are available to simulate the water temperature of freshwater bodies (Janssen et al., 2015). From a predictive and management point of view, the most appropriate models would be process-based ones, which take into account many forcing variables (meteorology, hydrology) and characteristics of the water body (morphology, outlet depth, etc.). Given the complexity of this type of models, they require the determination of many parameter values as well as temperature series of a reasonable length for calibration and validation for each of the modelled water bodies. Since these data were missing or were difficult to obtain for most of the water bodies at the moment of making the study, it may be useful to use simpler models such as the model by Ottosson and Abrahamsson (1998) and the four-parameter air2water model by Toffolon et al. (2014), of statistical and semi-empirical nature, or the simple process-based model FLake (Mironov, 2008), based on the autosimilarity concept and not requiring inflow and outflow data.

To obtain a better knowledge of the thermal behaviour of French water bodies, we were especially interested in the model of Ottosson and Abrahamsson (1998), that simulates water temperature using only lake morphometric and geographical data as input data. This model extended the monthly epilimnion temperature model of Håkanson (1996) to calculate also hypolimnion temperature. Later, Håkanson and Boulion (2001) adapted the epilimnion temperature model to the weekly time scale. However, these models are not able to reproduce the variability at the daily and interannual scale. In addition, when applied to French water bodies the model did not reproduce well the average epilimnion temperatures (Bouchez, 2010). We thus extended this model to include variability at the intra-annual and interannual time scales using air temperature as input data following Kettle et al. (2004). The resulting Ottosson-Kettle (OK) model has seven parameters. We applied and tested it on 476 water bodies. We developed a parameterization adapted to this set of lakes by using satellite and in situ data. The results were compared to those of two widely used water temperature models: (i) FLake model, which uses several input variables (Mironov, 2008), and (ii) the four-parameter air2water model by Toffolon et al. (2014) that simulates only epilimnion temperature as a function of air temperature. In addition to the water temperature series provided by the model, the regionalisation of its parameters provided interesting insights into the thermal behaviour of inland water bodies. 


\section{Data}

\subsection{Study case}

We tested our model on 476 lakes located in metropolitan France with surface area $\geq 0.5 \mathrm{~km}^{2}$. We extracted geographical, morphological and environmental data for these lakes from the PLAN_DEAU database (Tab. 1), maintained by the AFBIrstea research consortium on the hydrobiology of inland water bodies at Aix-en-Provence (France). The extracted variables were latitude $\left(L_{\text {Lat }},{ }^{\circ} \mathrm{N}\right)$, altitude $\left(L_{\mathrm{Alt}}, \mathrm{m}\right)$, maximum depth $\left(L_{\text {Dmax }}, \mathrm{m}\right)$, surface area $\left(L_{\mathrm{A}}, \mathrm{m}^{2}\right)$ and volume $\left(L_{\mathrm{V}}, \mathrm{m}^{3}\right)$, Secchi disk depth $\left(L_{\mathrm{SD}}, \mathrm{m}\right)$ and water body type $(Q$ : quarry lake; $P$ : pond; $G$ : gravel pit lake; $L$ : natural lake; $R$ : reservoir). Mean depth $\left(L_{\mathrm{D}}, \mathrm{m}\right)$ was calculated as $L_{\mathrm{D}}=L_{\mathrm{V}} / L_{\mathrm{A}}$. Lake latitude and continentality were measured at the centre of the lake. For lakes with significant water level variation, altitude surface area and volume were estimated at the maximal water level. The studied water bodies included both natural (64 natural lakes) and artificial water bodies (328 reservoirs, 42 ponds, 36 gravel pit lakes and 6 quarry lakes).

\subsection{Meteorological data}

To force the water temperature models we extracted the daily meteorological data from the SAFRAN reanalysis (Quintana-Seguí et al., 2008; Vidal et al., 2010), which is provided at an $8 \mathrm{~km} \times 8 \mathrm{~km}$ spatial resolution. For each water body, the nearest grid cell data was selected. We used air temperature as input data for air2water and the OK model. FLake meteorological forcing is solar radiation, air temperature, vapour pressure, wind speed and cloud cover. We applied an elevation correction to air temperature data to account for the difference in altitude between the water body and the

Table 1. Characteristics of the studied water bodies.

\begin{tabular}{lllll}
\hline Variable & Symbol & Minimum & Median & Maximum \\
\hline Altitude $(\mathrm{m})$ & $L_{\mathrm{Alt}}$ & 0.0 & 239.5 & 2841.0 \\
Latitude $\left({ }^{\circ} \mathrm{N}\right)$ & $L_{\mathrm{Lat}}$ & 41.47 & 46.25 & 50.87 \\
Longitude $\left({ }^{\circ} \mathrm{E}\right)$ & $L_{\mathrm{Lon}}$ & -4.24 & 2.33 & 9.48 \\
Maximum depth $(\mathrm{m})$ & $L_{\mathrm{Dmax}}$ & 0.8 & 15.0 & 309.7 \\
$\begin{array}{l}\text { Maximum surface } \\
\text { area }\left(\mathrm{m}^{2}\right)\end{array}$ & $L_{\mathrm{A}}$ & $6.0 \times 10^{4}$ & $7.7 \times 10^{5}$ & $5.8 \times 10^{8}$ \\
$\begin{array}{l}\text { Maximum } \\
\text { volume }\left(\mathrm{m}^{3}\right)\end{array}$ & $L_{\mathrm{V}}$ & $1.2 \times 10^{5}$ & $4.6 \times 10^{6}$ & $8.9 \times 10^{10}$ \\
\hline
\end{tabular}

SAFRAN grid cell. A constant adiabatic correction of $-0.0065^{\circ} \mathrm{C} / \mathrm{m}$ is often used. However, the air temperature lapse rates vary in time and space (Dodson and Marks, 1997; Rolland, 2003), and it is more appropriate to use a variable correction. Temperatures at different pressure levels simulated by climate models can be used to estimate variable lapse rates (Mokhov and Akperov, 2006; Gao et al., 2012) and this method has already been used for lake temperature simulations (Woolway et al., 2017). Since the standard SAFRAN output does not include temperature at different pressure levels, we preferred to estimate the air temperature daily lapse rate as the slope of the regression between the elevation and air temperature of the 50 pixels located nearest to each water body. These pixels are located in a radius of $\sim 30 \mathrm{~km}$ around the water body, reflecting the local meteorological conditions. In most cases, the altitudinal difference between the lake and the grid cell was small and only a small correction was needed, of the order of a few tenths of degree.

\subsection{Water temperature data}

In situ profile temperature measurements were used to parameterise the OK model (Sect. 5) and to assess its performance (Sect. 6). Secchi disk measurements were also used as input data for FLake. Temperature profiles and Secchi disk depths were obtained from measurements made by the French water quality networks, namely the Réseau de Contrôle de Surveillance (RCS) and the Réseau de Contrôle Opérationnel (RCO). These data were extracted from the PLAN DEAU data base on 7 March 2017 and were available for $87 \%$ of the studied water bodies $(n=414)$. The number of measured profiles per water body varied between 1 and 90, but usually monitoring takes place every three years and at least four measurements are taken during that year. For most water bodies in the data base (92\%) there were at most 12 profiles available. Plus, hourly profiles were obtained from the French continuous network of lake water temperature for five water bodies (Tab. 2).

We obtained surface skin temperature data measured by Landsat 5 TM and Landsat 7 ETM + for 1999-2016 from the data set LakeSST (Prats et al., 2018a). In usual conditions for water bodies, satellite-derived temperatures were available every 16 days for a given satellite. Since Landsat 5 and Landsat 7 have identical orbits with a delay of 8 days, satellite images for a given water body could be obtained every 8 days when both satellites were active (Landsat 5 was decommissioned in 2013). This optimal periodicity of measurement was reduced because of the presence of clouds (Tolnai et al., 2016), water

Table 2. Characteristics of the five water bodies with continuous measurements.

\begin{tabular}{lllllllll}
\hline Name & Code & Type $^{*}$ & Altitude $(\mathrm{m})$ & Latitude $\left({ }^{\circ} \mathrm{N}\right)$ & Longitude $\left({ }^{\circ} \mathrm{E}\right)$ & Max. depth $(\mathrm{m})$ & Max. surface $\left(\mathrm{m}^{2}\right)$ & ${\text { Max. Volume }\left(\mathrm{m}^{3}\right)}$ \\
\hline Aulnes & AUL13 & $L$ & 11 & 43.591 & 4.792 & 5.5 & $8.75 \times 10^{5}$ & $3.34 \times 10^{6}$ \\
Bimont & BIM13 & $R$ & 330 & 43.547 & 5.551 & 55.0 & $1.19 \times 10^{6}$ & $1.40 \times 10^{7}$ \\
Pierre-Châtel & LPC38 & $L$ & 923 & 44.974 & 5.778 & 10.3 & $9.66 \times 10^{5}$ & $6.40 \times 10^{6}$ \\
Pavin & PAV63 & $L$ & 1196 & 45.496 & 2.889 & 96.0 & $4.52 \times 10^{5}$ & $2.30 \times 10^{7}$ \\
Sainte-Croix & SCR04 & $R$ & 477 & 43.766 & 6.186 & 83.0 & $2.20 \times 10^{7}$ & $7.67 \times 10^{8}$ \\
\hline
\end{tabular}

${ }^{*} L$ : natural lake, $R$ : reservoir. 
vapour content beyond the limit of applicability of the algorithm used to estimate surface temperatures (Prats et al., 2018a) or because of technical and cost limitations in the number of images that could be acquired (Goward et al., 2006; Wulder et al., 2016). The number of satellite images per water body varied between 6 and 205, although the median number was 59 (less than 4 images per year in average).

We used the median temperature for each date as an estimation of the average surface temperature. We corrected the seasonal bias $b_{e}$ following (Prats et al., 2018a):

$$
\begin{gathered}
T_{\text {skin }}=T_{\text {skin,uncorr }}-b_{e} \\
b_{e}=-1.56+8.725 \times 10^{-4} R_{s}
\end{gathered}
$$

where $T_{\text {skin }}$ is the skin temperature $\left({ }^{\circ} \mathrm{C}\right), T_{\text {skin,uncorr }}$ is the uncorrected skin temperature $\left({ }^{\circ} \mathrm{C}\right)$ and $R_{S}$ is the average solar radiation $\left(\mathrm{J} \mathrm{cm}^{-2}\right)$. We estimated the epilimnion temperature as:

$$
T_{e}=T_{\text {skin }}-\Delta T_{c}-\Delta T_{w}
$$

where $\Delta T_{c}$ is the cool skin effect $\left({ }^{\circ} \mathrm{C}\right)$ and $\Delta T_{w}$ is the warm layer effect $\left({ }^{\circ} \mathrm{C}\right)$. We used constant values of $\Delta T_{c}=-0.46$ and $\Delta T_{w}=0.12$, based on the average cool skin and warm layer effects estimated at the reservoir of Bimont at the time of the satellite overpass (Prats et al., 2018a).

\subsection{Data availability}

The extraction of data from the PLAN_DEAU database (lake characteristics, temperature profiles, Secchi disk measurements) is available by request to the AFB-Irstea consortium on the hydrobiology of inland water bodies (contact: pierrealain.danis@afbiodiversite.fr). Meteorological SAFRAN data may be requested to Météo-France (https://donneespubliques. meteofrance.fr/). Charges are applicable to requests for commercial use. The LakeSST v. 1.2 data set containing satellite-derived skin temperatures can be downloaded from Zenodo (doi: 10.5281/zenodo.1193745).

\section{Water temperature models}

\subsection{Ottosson-Kettle model}

This model is based on the division of the water column into two layers: the upper layer or epilimnion, and the lower denser layer or hypolimnion. We will use this distinction even when the temperature is homogeneous in the water column. During these periods of time the epilimnion and hypolimnion temperature simulated by the model are equal.

We adapted the epilimnion temperature module following Kettle et al. (2004) as:

$$
T_{e, i}=A+B f\left(T_{a, i}^{*}\right)+C S_{i}
$$

where $T_{e, i}$ is the epilimnion temperature, $S$ is the solar radiation $\left(\mathrm{W} \mathrm{m}^{-2}\right.$ ), $i$ is the day number and $A, B, C$ are calibration parameters. In contrast to Kettle et al. (2004), instead of using the theoretical clear-sky radiation, we used a sinusoidal fitted to average daily solar radiation data. The variable $T_{a, i}^{*}$ was defined as:

$$
T_{a, i}^{*}=T_{a, i}-\text { MAAT }
$$

where $T_{a, i}$ is air temperature and MAAT is the mean annual air temperature for the study period or for a relevant reference period. The function $f(*)$ is an exponential smoothing function such that:

$$
\begin{gathered}
f\left(T_{a, 1}^{*}\right)=T_{a, 1}^{*} \\
f\left(T_{a, i}^{*}\right)=\alpha T_{a, i}^{*}+(1-\alpha) f\left(T_{a, i-1}^{*}\right)
\end{gathered}
$$

where $\alpha$ is the smoothing factor. When $T_{e, i}<0{ }^{\circ} \mathrm{C}$, we make $T_{e, i}=0{ }^{\circ} \mathrm{C}$.

We adapted the hypolimnion temperature module from Ottosson and Abrahamsson (1998):

$$
T_{h, i}=A \cdot D+E \cdot g\left(T_{e, i}\right)
$$

where $T_{h, i}$ is the hypolimnion temperature, $D$ and $E$ are calibration parameters and the function $g(*)$ is a simple exponential smoothing of $T_{e}$ :

$$
\begin{gathered}
g\left(T_{e, 1}\right)=T_{e, 1} \\
g\left(T_{e, i}\right)=\beta T_{e, i}+(1-\beta) g\left(T_{e, i-1}\right)
\end{gathered}
$$

where $\beta$ is the exponential smoothing factor.

Finally, we simplified the mixing algorithm used by Ottosson and Abrahamsson (1998) and we used a basic stability condition, i.e. if the epilimnion density is higher than the hypolimnion density, then we make $T_{h, i}=T_{e, i}$, and if $T_{h, i}<4^{\circ} \mathrm{C}$, then $T_{h, i}=4{ }^{\circ} \mathrm{C}$, assuming a minimum hypolimnion temperature of $4{ }^{\circ} \mathrm{C}$. To avoid discontinuities due to this condition, the equation (8) was implemented as:

$$
T_{h, i}=T_{h, i-1}+\Delta T_{h}
$$

where

$$
\Delta T_{h}=E\left[g\left(T_{e, i}\right)-g\left(T_{e, i-1}\right)\right]
$$

If the stability condition is not applied, that is, if the hypolimnion temperature is above $4^{\circ} \mathrm{C}$ all the time, the equations (8) and (11) are equivalent.

\subsection{Four-parameter version of air2water model}

The four-parameter version of the air2water model (Toffolon et al., 2014; Piccolroaz, 2016) is a simplification of the full 8-parameter model by Piccolroaz et al. (2013) to estimate the epilimnion temperature of lakes in the temperate region (Piccolroaz et al., 2015; Czernecki and Ptak, 2018; Piccolroaz et al., 2018). It is a semiempirical model that approximates the heat balance from air and water temperature according to:

$$
\frac{d T_{e}}{\mathrm{~d} t}=\frac{1}{\delta}\left(a_{1}+a_{2} T_{a}-a_{3} T_{e}\right)
$$


where $T_{e}$ is the epilimnion temperature, $T_{a}$ is the air temperature, $a_{1}, a_{2}$ and $a_{3}$ are model parameters and $\delta$ is the proportion of the mixing layer volume respect to total volume, estimated as:

$$
\delta=\left\{\begin{array}{cc}
\exp \left(-\frac{T_{e}-T_{h}}{a_{4}}\right) & T_{e} \geq T_{h} \\
1 & T_{e}<T_{h}
\end{array}\right.
$$

where $T_{h}$ is the hypolimnion temperature and $a_{4}$ is a model parameter. Toffolon et al. (2014) suggest taking $T_{h}=4{ }^{\circ} \mathrm{C}$ for dimictic water bodies, the minimum temperature for warm monomictic water bodies and maximum temperature for cold monomictic water bodies. The quality of the calibration of the four-parameter version of air 2 water is doubtful for percentages of missing data above $97 \%$, which corresponds roughly to monthly measurements (Piccolroaz, 2016). For most water bodies in the LakeSST data set the percentage of missing data was higher, so that we used the parameterization presented by Toffolon et al. (2014) derived from a set of 14 lakes from different geographical regions and different spans of time of available data:

$$
\begin{aligned}
& a_{1}=-0.042+0.017 \ln L_{D} \\
& a_{2}=0.223 L_{D}^{-0.635} \\
& a_{3}=0.175 L_{D}^{-0.540} \\
& a_{4}=35.4 L_{D}^{-0.360}
\end{aligned}
$$

However, we calibrated the model for the five sites with continuous measurements to check the effect of the calibration. The initial water temperature was estimated as the median temperature in the months of December and January calculated using the regression derived from satellite measurements:

$$
\begin{aligned}
T_{\text {Dec-Jan }}= & 26.1-0.49 L_{\text {Lat }}-0.0030 L_{\mathrm{Alt}}+0.21 \ln L_{V} \\
& +0.0091 L_{\text {Dmax }}
\end{aligned}
$$

with root mean square error $(\mathrm{RMSE})=1.3{ }^{\circ} \mathrm{C}$ and Kendall's tau $=0.54$.

\subsection{FLake}

FLake (http://www.flake.igb-berlin.de/) is a 1D hydrodynamic model, designed as a module to be used by weather and climate prediction numerical models (Mironov, 2008) that has been applied to many lakes around the world (e.g., Bernhardt et al., 2012; Kirillin et al., 2013; Heiskanen et al., 2015; Layden et al., 2016). FLake takes into account convective and wind mixing processes, and uses a heat balance to calculate the variation of the content of heat in the water body. Water temperature in the mixing layer is assumed to be uniform.
Below the mixing layer, the vertical thermal structure is described using the autosimilarity concept.

FLake uses the following forcing variables: solar radiation, air temperature, air vapour pressure, wind speed and cloudiness. The model does not have calibration parameters and the only lake-specific parameters are mean depth, the optical characteristics of water, the temperature at the bottom of the sediment thermal active layer and the depth of this layer.

Since FLake was not developed for deep lakes and following the recommendations of its developers (http://www. flake.igb-berlin.de/usefulhints.shtml), we fixed the mean depth to $50 \mathrm{~m}$ for the 13 water bodies deeper than $50 \mathrm{~m}$ to limit simulation errors. Calculations were made with a daily time step. As for air2water, the initial temperature was estimated with the equation (19).

The light extinction coefficient $k$ was calculated as:

$$
k=1.7 / L_{\mathrm{SD}}
$$

where $L_{\mathrm{SD}}$ is the median of Secchi Disk depth measurements (m) during the study period for each water body. The sediment heat exchange was deactivated.

\subsection{Code availability}

The source code of the OK model is available at Irstea source forge (https://forge.irstea.fr/projects/templac). Access is granted upon request to the authors. The source code and a Windows executable of FLake can be downloaded from FLake website: http://www.flake.igb-berlin.de/sourcecodes.shtml The source code of air2water is available from github: https:/github.com/marcotoffolon/air2water. An independent implementation of the 4-parameter version of the model made by the authors and used in this paper is available at Irstea source forge (https://forge.irstea.fr/projects/templac).

\section{Numerical calculations and statistical analysis}

The three models to estimate epilimnion and hypolimnion temperatures were implemented in Python 2.7. We used the packages numpy (van der Walt et al., 2011) and scipy (McKinney, 2010). We used the L-BSFG-B algorithm (Byrd et al., 1995) to calibrate the parameter values for each water body.

The statistical calculations were made using $\mathrm{R}$ ( $\mathrm{R}$ Core Team, 2015) and the tidyverse (Wickham, 2017). We favoured robust and nonparametric methods. Thus, all regressions presented for the estimation of the OK model parameters are robust regressions, made using the package MASS (Venables and Ripley, 2002). We used the Wilcoxon signed-rank test (Wilcoxon, 1945) to test departures from zero and to compare paired groups, and the Kruskal-Wallis $H$ test (Kruskal and Wallis, 1952) to test the existence of differences between groups. To identify differences between groups we used the Conover test (Conover and Iman, 1979), from the package PMCMRplus (Pohlert, 2018), as a posthoc test after the Kruskal-Wallis one-way analysis of variance. 
We used the BIC criterion (Raftery, 1995) to select the best regression model for the parameters $\alpha, A, B$ and $C$. First, we ranked all possible models depending on the morphologic and geographical variables $\left(L_{\text {Dmax }}, \ln L_{\text {Dmax }}, \ln L_{A}\right.$, $\ln L_{V}, L_{\text {Lat }}, L_{\text {Alt }}$, MAET) according to the value of the BIC criterion using the $\mathrm{R}$ package MuMIn (Barton, 2018). Then we applied an Occam's window, by selecting the model with the lowest BIC and all models with $\Delta \mathrm{BIC}<2$. Finally, we chose the most parsimonious model among the remaining models.

We used the R package tabulizer (Leeper, 2018) to extract from a pdf document the data shown in the Figures 4 and 5 from Kettle et al. (2004). The data were checked after extraction and corrected where necessary.

\section{Parameterization of the Ottosson-Kettle model for French lakes}

The model parameterization was made separately for the epilimnion and for the hypolimnion temperature modules. The parameter values were calibrated for the study lakes and then parameterized as a function of lake characteristics.

\subsection{Epilimnion temperature}

The four parameters of the epilimnion module $\alpha, A, B$ and $C$ were calibrated using satellite image data for French lakes in the period 1999-2016.

\subsubsection{Parameter $A$}

In all-year-round ice-free water bodies, the parameter $A$ corresponds to the mean annual epilimnion temperature (MAET) (Ottosson and Abrahamsson, 1998). For lakes with ice cover during part of the year, the parameter $A$ corresponds to the mean of a sinusoidal function fitted to the temperature data during the ice-free period. We fitted a multiple robust regression between MAET and lake latitude $\left(L_{\text {Lat }}\right)$, altitude $\left(L_{\mathrm{Alt}}\right)$ and surface area $\left(L_{A}\right)$ :

$A=$ MAET $=39.9-0.484 L_{\text {Lat }}-0.00452 L_{\text {Alt }}-0.167 \operatorname{In} L_{A}$,

with an RMSE of $0.74^{\circ} \mathrm{C}$ and Kendall's tau of 0.64 (Fig. 1). Of the coefficients of the equation (21) the one multiplying $\ln L_{A}$ is the one with the lowest $p$-value $\left(p\right.$-value $\left.=3.9 \times 10^{-8}\right)$. For the other coefficients, $p$-value $<10^{-16}$.

\subsubsection{Parameter $\alpha, B$ and $C$}

Using the value of $A$ calculated with equation (21), the value of the coefficients $\alpha, B$ and $C$ were calibrated for each water body. The combinations of parameter values for which $\alpha<0.01$ were discarded as physically implausible and were deemed to be calibration artefacts. The distribution of the fitted values for the three parameters is shown in the Figure 2. The parameter $\alpha$ varied between 0.03 and 0.64 , with a median of $0.19 ; B$ varied between 0.61 and 1.35 , with a median of 1.05 ; and $C$ varied between -0.025 and 0.010 , with a median of 0.0002 .

Initially, following Kettle et al. (2004), we fitted the value of $\tau=1 / \alpha$ instead of $\alpha$. However, this causes a high uncertainty in the prediction of high values of $\alpha$, with a Kendall's tau correlation of 0.65 between fitted and estimated values and an RMSE of 0.22 . Instead, it seemed preferable to fit $\ln \alpha$. In fact, $\ln \tau=\ln (1 / \alpha)=-\ln \alpha$. Using the BIC criterion, we fitted a multiple linear regression function of the lake altitude $\left(L_{\mathrm{Alt}}\right)$, surface $\left(L_{A}\right)$ and volume $\left(L_{V}\right)$ :

$$
\ln \alpha=0.52-3.0 \times 10^{-4} L_{\text {Alt }}+0.25 \ln L_{A}-0.36 \ln L_{V}
$$

So that

$$
\alpha=\exp \left(0.52-3.0 \times 10^{-4} L_{\mathrm{Alt}}+0.25 \ln L_{A}-0.36 \ln L_{V}\right)
$$

Now, Kendall's tau correlation coefficient was 0.66 and the RMSE was lower, 0.08. Although there was still higher uncertainty for high values of $\alpha$, it was greatly reduced (Fig. 3). The Figure 3 also shows that the estimations of $\alpha$ using equation (5) in Kettle et al. (2004) were lower than those made with equation (23). The parameter $B$ showed a small variability, with $90 \%$ of the values comprised between 0.89 and 1.15 . Still, it showed a dependence on maximum depth $\left(L_{\text {Dmax }}\right)$ :

$$
B=1.058-0.0010 L_{\operatorname{Dmax}}
$$

The estimated values of $B$ had RMSE $=0.08$ and Kendall's tau $=0.10$. In contrast to Kettle et al. (2004) (Tab. 3), in our case the relation between $B$ and $L_{\text {Dmax }}$ seemed linear rather than logarithmic (Fig. 4). Regarding the parameter $C$, model selection based on the BIC criterion showed it depended mostly on volume, MAET and maximum depth (Fig. 5):

$$
C=1.12 \times 10^{-3}-3.62 \times 10^{-6} L_{\mathrm{Alt}}
$$

with RMSE $=0.004{ }^{\circ} \mathrm{C} \mathrm{m}^{2} \mathrm{~W}^{-1}$ and Kendall's tau $=0.22$.

\subsection{Hypolimnion temperature}

Using the epilimnion parameter values estimated with equations (21-25), we calibrated the hypolimnion parameters $\beta$ and $E$ for each water body using profile data for 411 water bodies from the PLAN_DEAU data base for the period 19992016. Only the parameter values for the 357 water bodies for which the fitting was successful were kept.

\subsubsection{Parameter $D$}

Above a certain value, the model was insensitive to the value of the parameter $D$. This critical value depended on the value of $E$, being greater for greater values of $E$. Since there were few water bodies with winter profile data and because of the interaction between parameters it was difficult to calibrate $D$ and we kept the constant value $D=0.51$ proposed by Ottosson and Abrahamsson (1998). This value may be considered as the minimum value to assure there is autumn overturn independently of the value of $E$. For low 

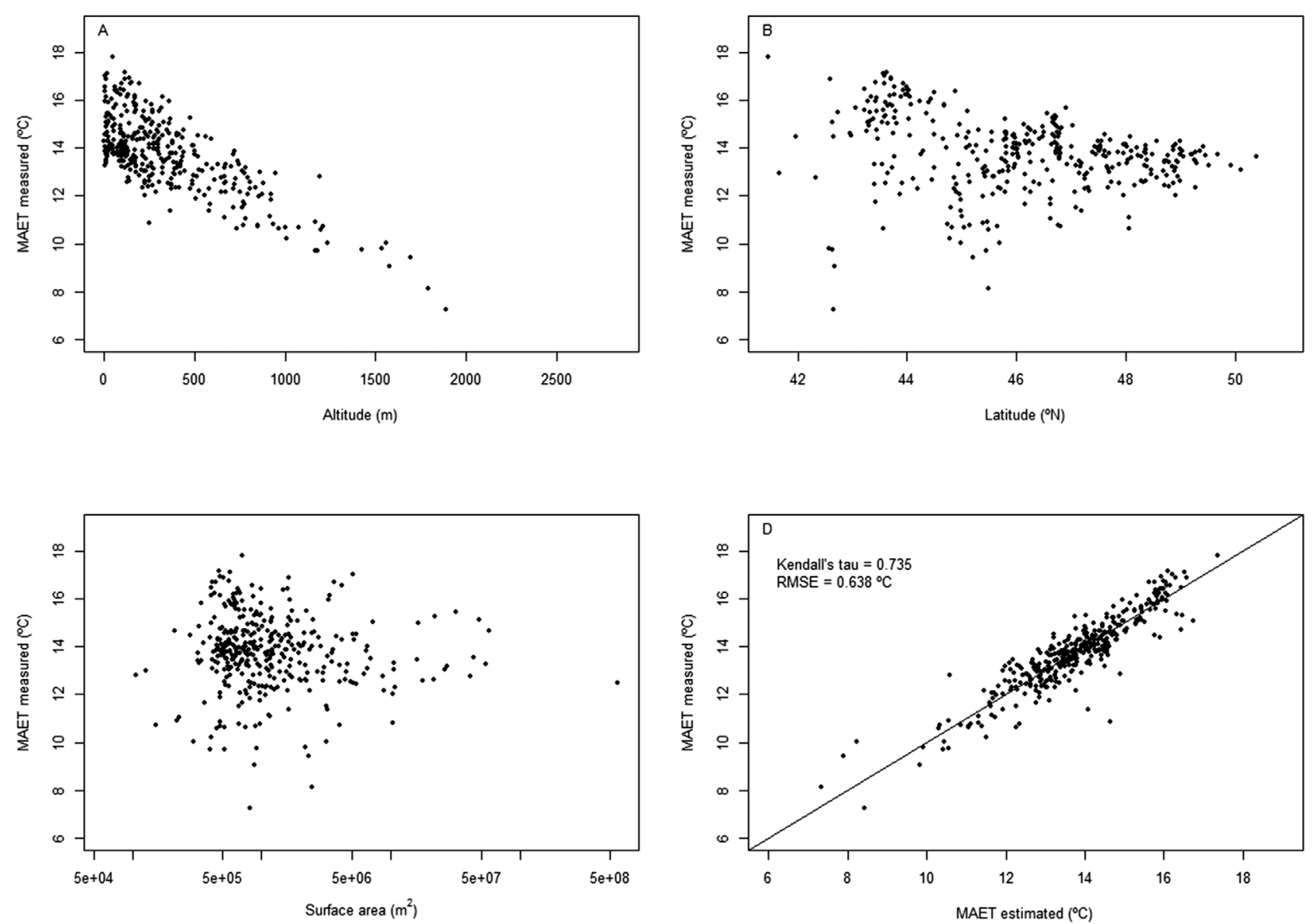

Fig. 1. Measured MAET as a function of altitude (A), latitude (B) and surface area (C), and comparison with MAET estimated with equation (21) (D). The diagonal line indicates the 1:1 relation.
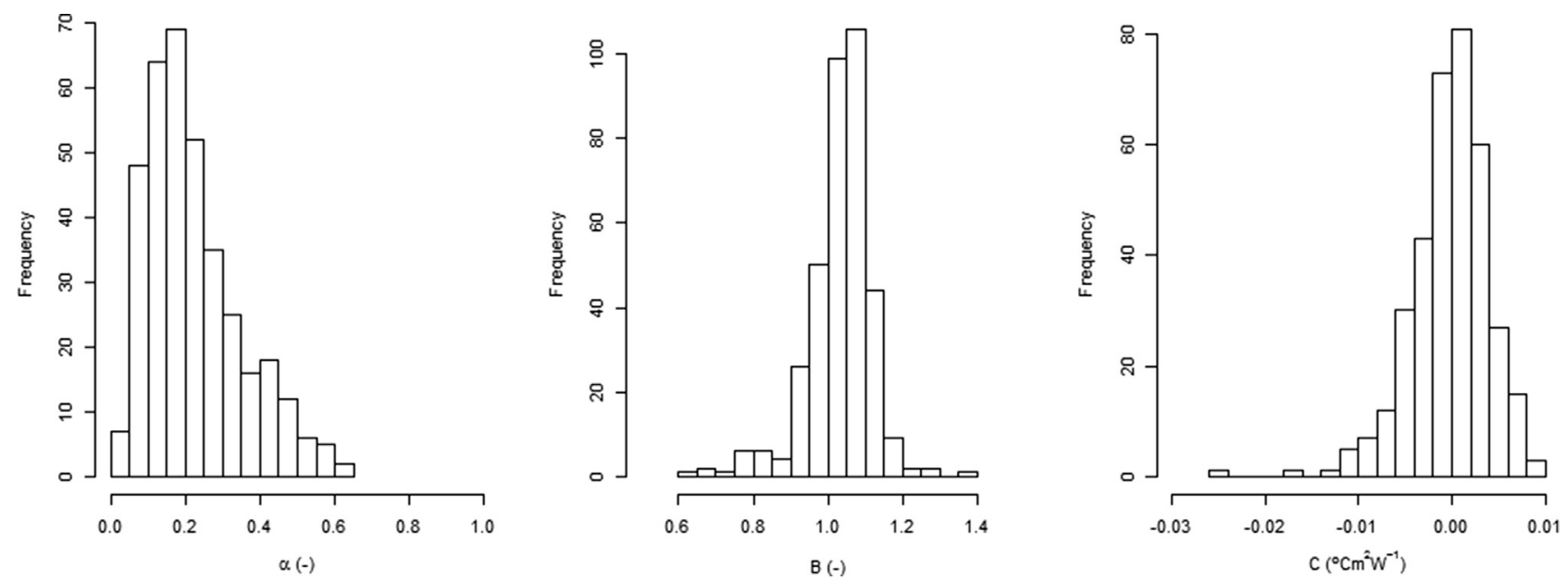

Fig. 2. Distribution of the fitted values of the parameters $\alpha, B$ and $C$. 


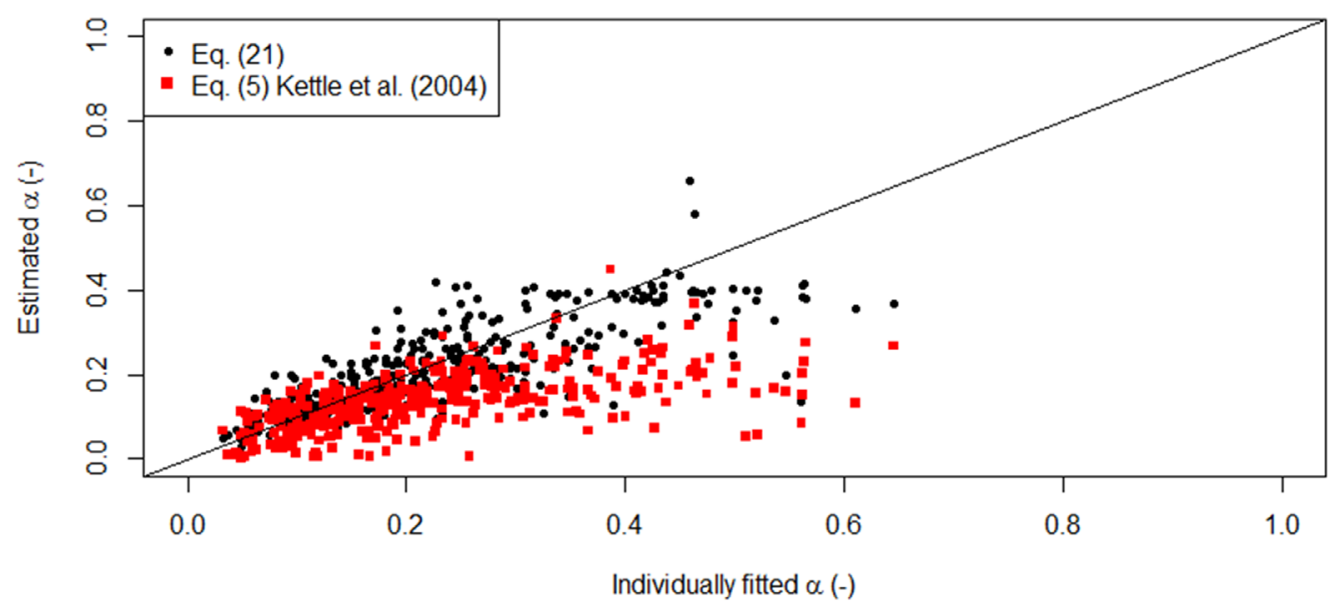

Fig. 3. Comparison between individually fitted values of $\alpha$ and values estimated using equation (23) in this paper and equation (5) in Kettle et al. (2004).

Table 3. Parameterisations of model parameters for different geographical regions.

Parameter Swede (Ottosson and Abrahamsson, 1998; Greenland (Kettle et al., 2004) France (this work) Håkanson and Boulion, 2001)

\begin{tabular}{llll}
\hline$\alpha$ & $\frac{6 c}{A \cdot L_{V}^{0.1}}$ & $\left(1+1.234 \ln L_{\mathrm{Dmax}}+0.035 L_{\mathrm{A}}\right)^{-1}$ & $\exp \left(0.52-3.0 \times 10^{-4} L_{\mathrm{Alt}}+0.25 \ln L_{\mathrm{A}}-0.36 \ln L_{\mathrm{V}}\right)$ \\
$A$ & $44-\left(\frac{750}{90-L_{\mathrm{Lat}}}\right)^{1.29}$ & $-1.86+1.672 \ln L_{\mathrm{Dmax}}$ & $39.9-0.484 L_{\mathrm{Lat}}-4.52 \times 10^{-3} L_{\mathrm{Alt}}-0.167 \ln L_{\mathrm{A}}$ \\
& $-0.1 L_{\text {Alt }}^{0.5}-0.25\left(L_{\mathrm{Cont}}^{0.9}+500\right)^{0.52}$ & & \\
& 1 & $1.087-0.125 \ln L_{\mathrm{Dmax}}$ & $1.058-0.0010 L_{\mathrm{Dmax}}$ \\
$B$ & 0 & $2.08 \times 10^{-2}-3.44 \times 10^{-4} L_{\mathrm{Dmax}}$ & $1.12 \times 10^{-3}-3.62 \times 10^{-6} L_{\mathrm{Alt}}$ \\
$C$ & $A^{-0.5}$ & - & $\left\{\begin{array}{l}1 \\
\beta\end{array}\right.$ \\
& 0.51 & - & $0.13 \quad E \leq 0.95$ \\
$D$ & $\frac{2.2}{L_{D}+0.1}+0.4$ & - & $e_{1}+\frac{1}{1+\exp \left[e_{3}\left(e_{2}-\ln L_{D}\right)\right]}$ \\
\hline
\end{tabular}

$L_{\mathrm{A}}$ : lake surface area $\left(\mathrm{m}^{2}\right), L_{\mathrm{D}}$ : lake mean depth $(\mathrm{m}), L_{\text {Dmax }}$ : lake maximum depth $(\mathrm{m}), L_{\mathrm{v}}$ : lake volume $\left(\mathrm{m}^{3}\right), L_{\mathrm{Alt}}:$ lake altitude $(\mathrm{m}), L_{\mathrm{Lat}}:$ lake latitude $\left({ }^{\circ} \mathrm{N}\right)$; $L_{\text {Cont }}$ : lake continentality $(\mathrm{km}) . c=1$ for monthly simulations, $c=12 / 52$ for weekly simulations, $c=12 / 365$ for daily simulations. $\left(e_{1}, e_{2}, e_{3}\right)=(0.10,2.0,-1.8)$ for natural lakes and $\left(e_{1}, e_{2}, e_{3}\right)=(0.49,1.7,-2.0)$ for artificial ones.

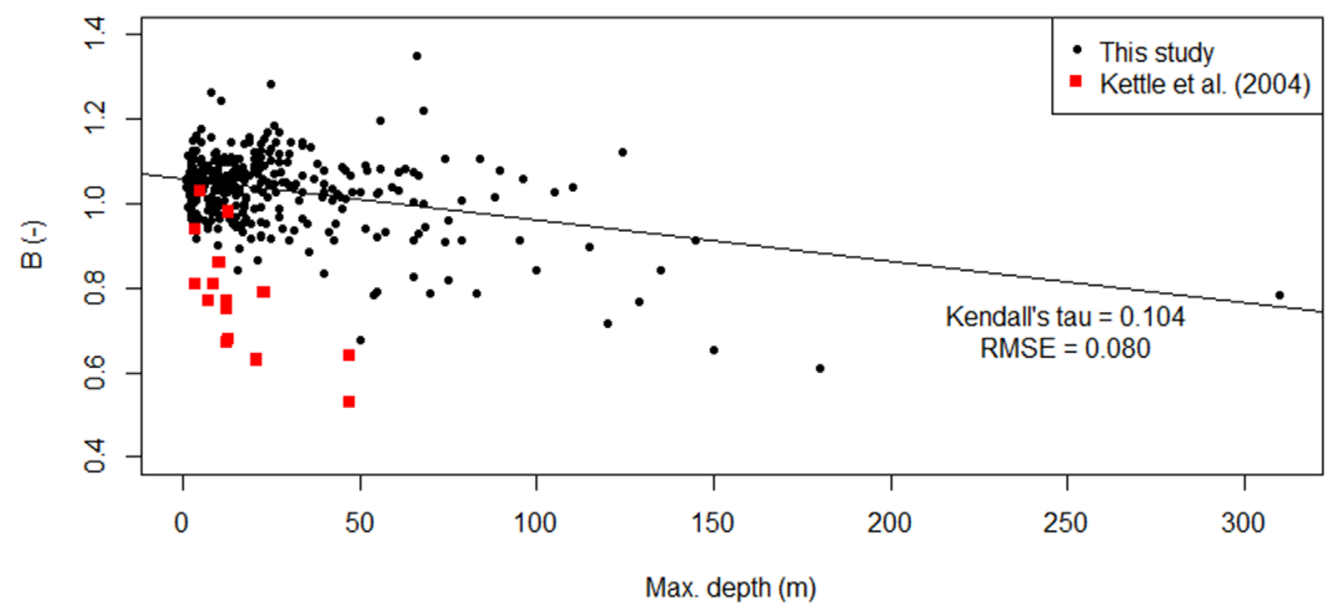

Fig. 4. Parameter $B$ as a function of and maximum depth. Fitted values for this study and for Kettle et al. (2004) and robust linear regression (Eq. (24)) for this study's data. 


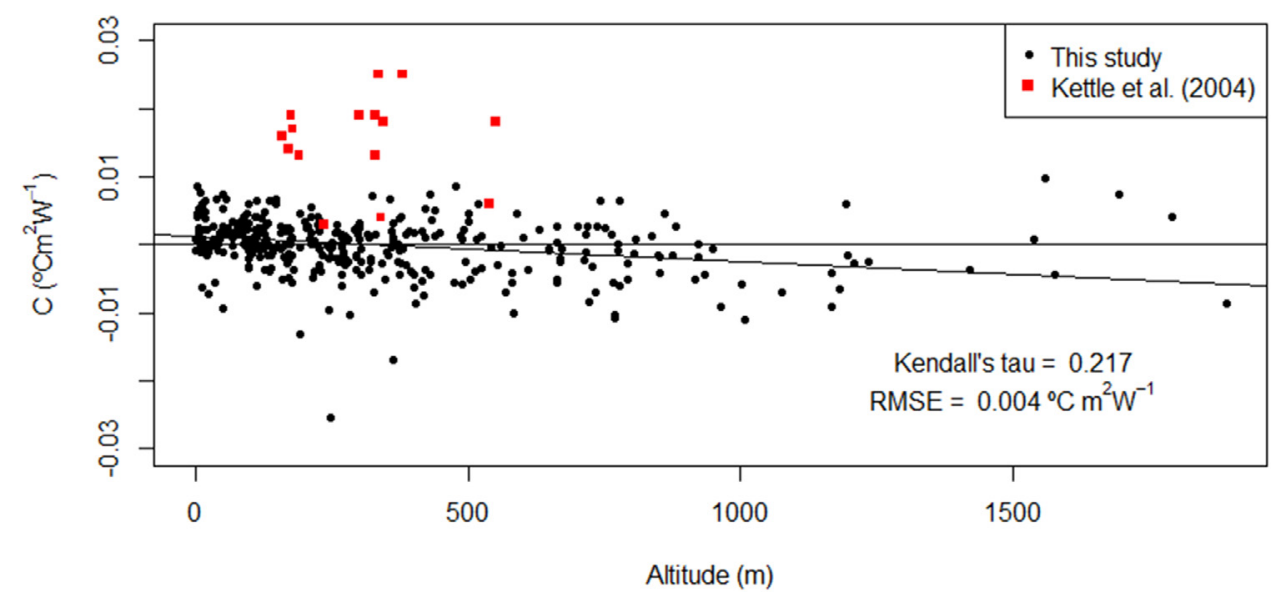

Fig. 5. Parameter $C$ as a function of altitude. Fitted values for this study and for Kettle et al. (2004) and robust linear regression (Eq. (25)) for this study's data.

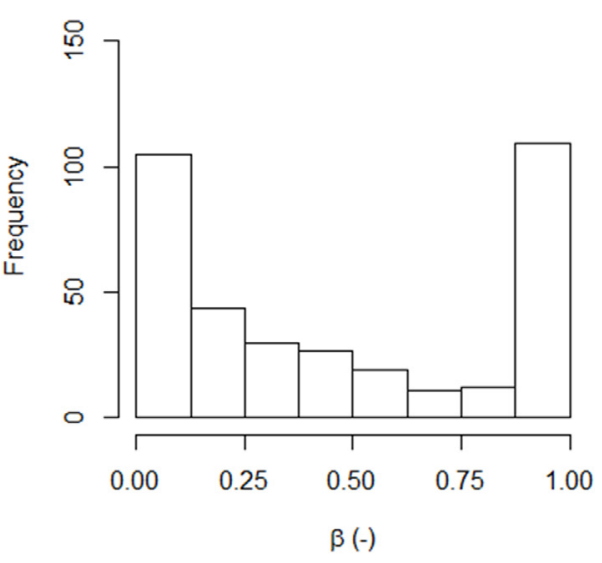

Fig. 6. Distribution of the fitted values of the parameters $\beta$ and $E$.

values of $D$, the epilimnion and hypolimnion temperature curves do not intersect, so that the mixing algorithm is not applied. That would be the case of a water body stratified all the year round.

\subsubsection{Parameters $\beta$ and $E$}

The fitted values of both parameters $\beta$ and $E$ vary between 0 and 1 and show an approximately bimodal distribution (Fig. 6). The parameter $\beta$ shows a peak at just above 0 and at 1 ; the parameter $E$ shows a peak at about 0.6 and at 1 . Their estimated joint distribution (Fig. 7) shows these bimodal distributions are related and linked to a threshold behaviour. The Figure shows two main groups of data points: (1) a group with values of $\beta$ and $E$ near or equal to 1; and (2) a group with a wide range of values of $E$ and low values of $\beta$ (around $\beta=0.13$ ). In fact, $\beta$ could be considered as a constant parameter with a threshold behaviour that depends on the value of $E$. In addition, the value of $E$ depends on depth (Fig. 8). For very shallow water bodies (up to $2-3 \mathrm{~m}$ deep), the value of $E$ is high (approx. $E>0.90$ ) and, since $T_{e} \approx T_{h}$, there is no smoothing and $\beta \approx 1$. When water bodies become deeper, the value of $E$ decreases and the value of $\beta$ decreases sharply, to values of about 0.13 .

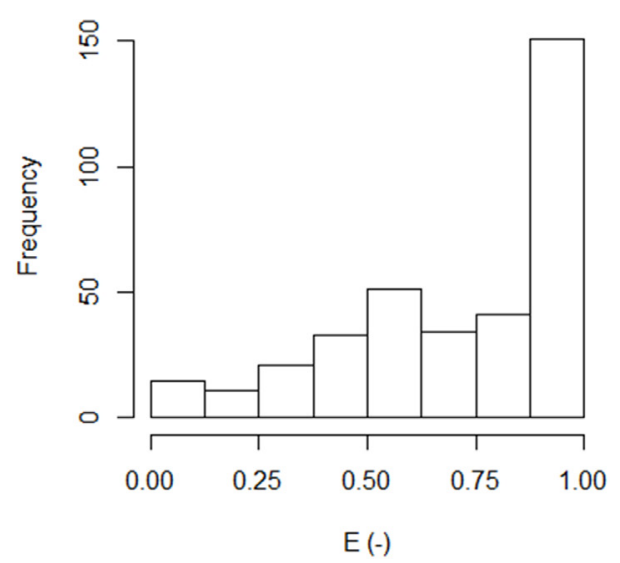

An appropriate value for the critical value of $E$ for stratification was obtained by analysing the relation between $E$ and the median of the difference between epilimnion and hypolimnion temperatures $\Delta T_{e h}=T_{e}-T_{h}$ for the months of July to September:

$$
E=1.01-0.062 \Delta T_{e h}
$$

that has an $\mathrm{RMSE}=0.15$ and a Kendall's tau $=0.65$. Assuming the frequently used criterion of a $1{ }^{\circ} \mathrm{C}$ difference between $T_{e}$ and $T_{h}$ for identifying stratification (Stefan et al., 1996; Foley et al., 2012; Woolway et al., 2014) and applying the equation (26), the critical value of $E$ should be 0.95 . We then parameterised $\beta$ as:

$$
\beta=\left\{\begin{array}{cc}
1 & E>0.95 \\
0.13 & E \leq 0.95
\end{array}\right.
$$

The values of $\beta$ thus estimated showed an RMSE of 0.41 and a Kendall's tau of 0.37 . Although for stratified water bodies $(E \leq \mathbf{0 . 9 5})$ the median value of $\beta$ was 0.21 , we used the value of 0.13 that corresponded to the maximum of the distribution of $\beta$ for stratified water bodies (Fig. 7). In support of this decision, the model was not very sensitive to the value 


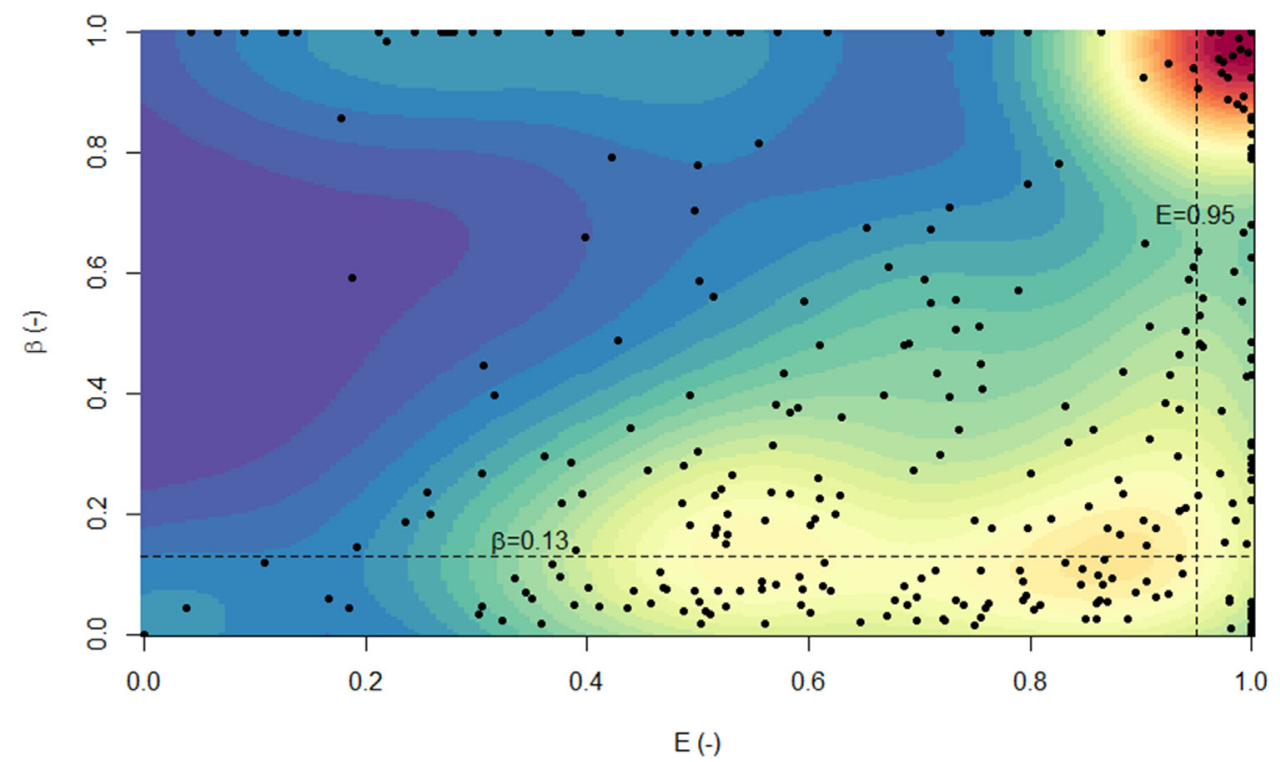

Fig. 7. Estimated kernel density of $(E, \beta)$.

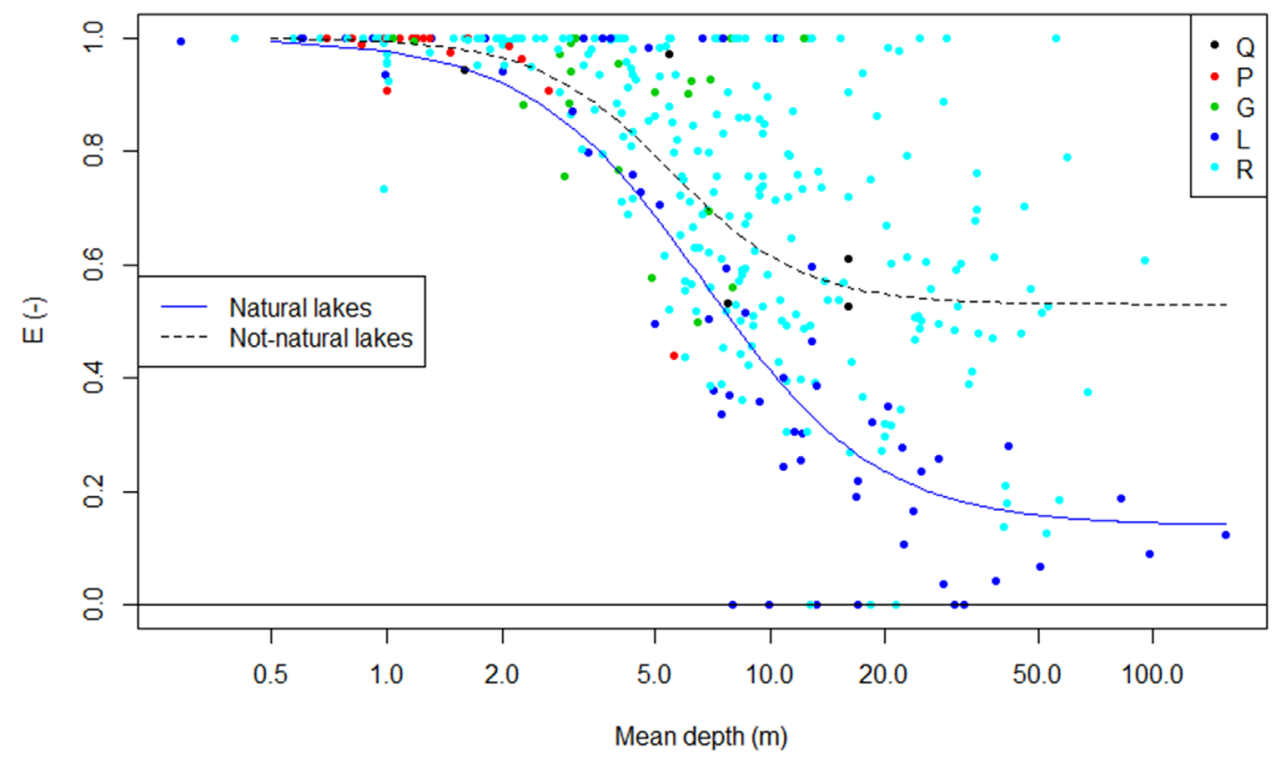

Fig. 8. Parameter $E$ as a function of depth and lake type ( $Q$ : quarry lake; $P$ : pond; $G$ : gravel pit lake; $L:$ natural lake; $R$ : reservoir). The lines indicate the estimations of $E$ according to equation (28) and the values in the Table 4.

of $\beta$ and, because of the great variability of the parameter, by using 0.21 instead of 0.13 in the equation (27) the RMSE of the estimated $\beta$ was almost equal, 0.39 . In addition, because of the low sensitivity of the model to $\beta$ and the paucity of profile measurements available, it was difficult to accurately estimate the value of $\beta$. In fact, a value of $\beta=0.13$ corresponds to an exponential smoothing time constant of 8 days, while most often the temperature profiles used for calibration were taken several months apart.

The parameter $E$ reflects the temperature gradient between the epilimnion and the hypolimnion. For $E \approx 1$, the water body can be considered polymictic $\left(T_{e} \approx T_{h}\right)$, and the lower the value of $E$ the more intense the stratification.
Figure 8 also shows that natural lakes tended to have lower values of $E$ than reservoirs, because reservoirs tend to have less intense stratification than natural lakes. Subsurface outlets present in many reservoirs cause the lowering of the thermocline and a more gradual temperature gradient (Han et al., 2000; Prats et al., 2018b). As a consequence, we defined two different parameterizations of $E$ as a function of lake depth, one for natural lakes and another for artificial lakes. We parameterized $E$ as a sigmoid function of lake depth $L_{\mathrm{D}}$ :

$$
E=e_{1}+\frac{1-e_{1}}{1+\exp \left[e_{3}\left(e_{2}-\ln L_{\mathrm{D}}\right)\right]},
$$


where the fitted values of the coefficients $e_{1}$ to $e_{3}$ can be found in Table 4. For this we used data points such that $E>0$ and $E<1$. For natural lakes RMSE was $\mathbf{0 . 1 8}$ and Kendall's tau was 0.65 ; for not-natural lakes RMSE was 0.18 and Kendall's tau was 0.52 .

\section{Model evaluation}

The simulation period was from 1 January 1999 to 31 December 2016. Two kinds of data were used to assess the performance of the three presented models: RCS-RCO networks profile measurements for 404 water bodies and continuous profile measurements for 5 water bodies.

Table 4. Fitted values of the coefficients of equation (28).

\begin{tabular}{llll}
\hline Type of water body & $e_{1}$ & $e_{2}$ & $e_{3}$ \\
\hline Natural lakes & $0.14^{* *}$ & $1.9^{* * *}$ & $-1.9^{* * *}$ \\
Artificial lakes & $0.53^{\text {*** }}$ & $1.7^{\text {*** }}$ & $-2.5^{* * *}$ \\
\hline
\end{tabular}

${ }^{* * *}$ Statistically significant with $p$-value $<0.001 ;{ }^{* *}$ statistically significant with $p$-value $<0.01$.

\subsection{Overall evaluation results}

The simulation results of the OK model are good in absolute terms and in comparison to the results of the other two models (Fig. 9). The epilimnion temperatures simulated using the $\mathrm{OK}$ model showed a small bias (median ME of $-0.49^{\circ} \mathrm{C}$, statistically different from zero with $p$-value $<0.001$ according to the Wilcoxon test) and an acceptable median RMSE of $1.7^{\circ} \mathrm{C}$. For hypolimnion temperatures, the model was unbiased, with a median ME of $-0.16^{\circ} \mathrm{C}$ $(p$-value $=0.07)$ and a median RMSE of $2.3{ }^{\circ} \mathrm{C}$. These performance statistics compare favourably to those of FLake and air2water models. For epilimnion temperature the median RMSE was $2.6^{\circ} \mathrm{C}$ for FLake and $2.3{ }^{\circ} \mathrm{C}$ for air2water. FLake simulated hypolimnion temperatures with a median RMSE of $3.3^{\circ} \mathrm{C}$.

The quality of the epilimnion temperature simulations was similar for most water body types (Fig. 10 left), with median RMSE between $1.3^{\circ} \mathrm{C}$ and $1.7^{\circ} \mathrm{C}$. The RMSE was lowest for quarry lakes but the differences between groups were not statistically significant $(p$-value $=0.19$ according to the Kruskal-Wallis test). Instead, there were differences between water body types for the hypolimnion simulations ( $p$-value $<0.001$ according to the Kruskal-Wallis test). There
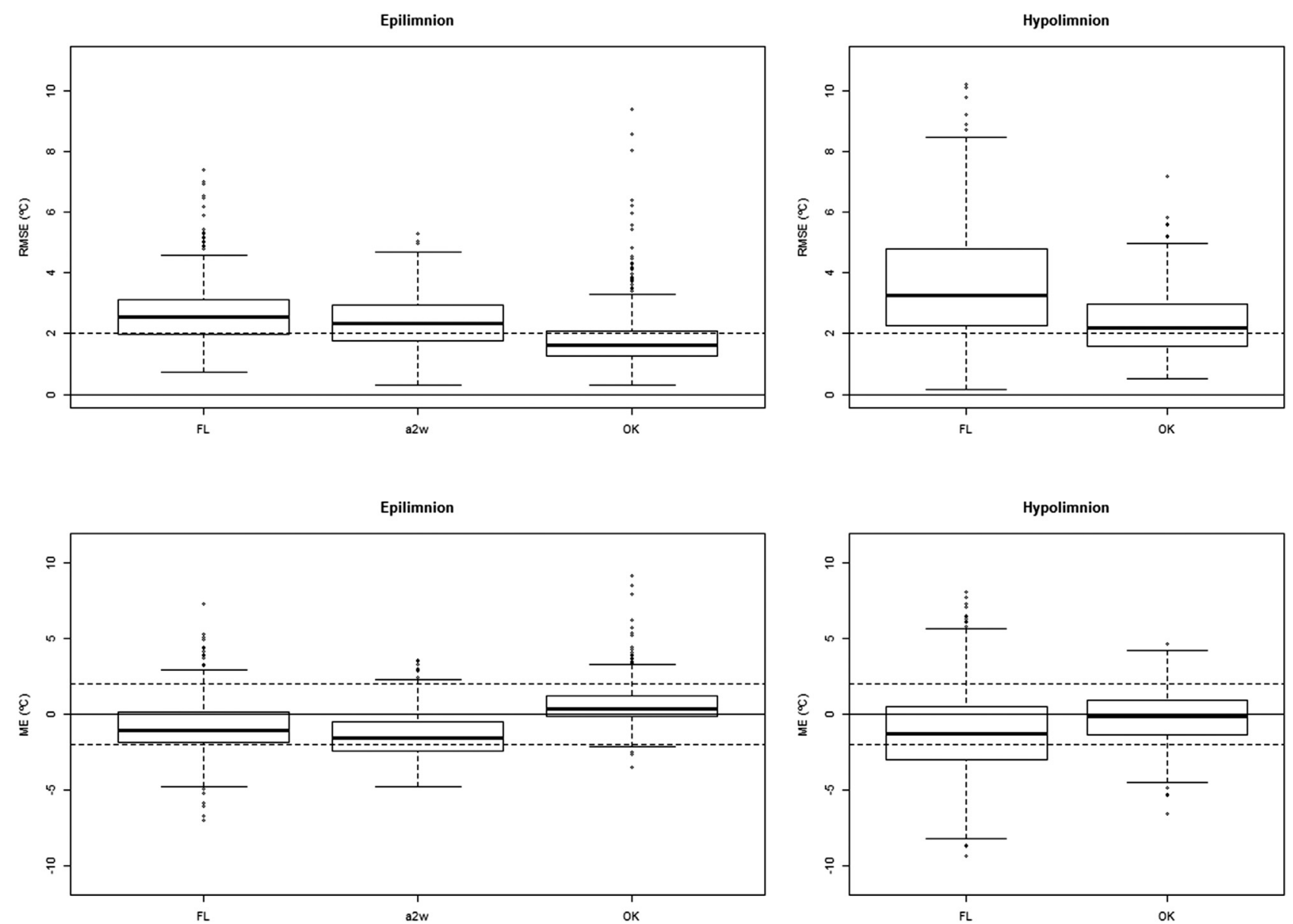

Fig. 9. Root mean square error (RMSE) and mean error (ME) of the simulation of epilimnion and hypolimnion temperatures for the three tested models (FL: FLake; OK: Ottosson-Kettle model; a2w: 4-parameter air2water). No hypolimnion temperatures are simulated by the a2w model. 

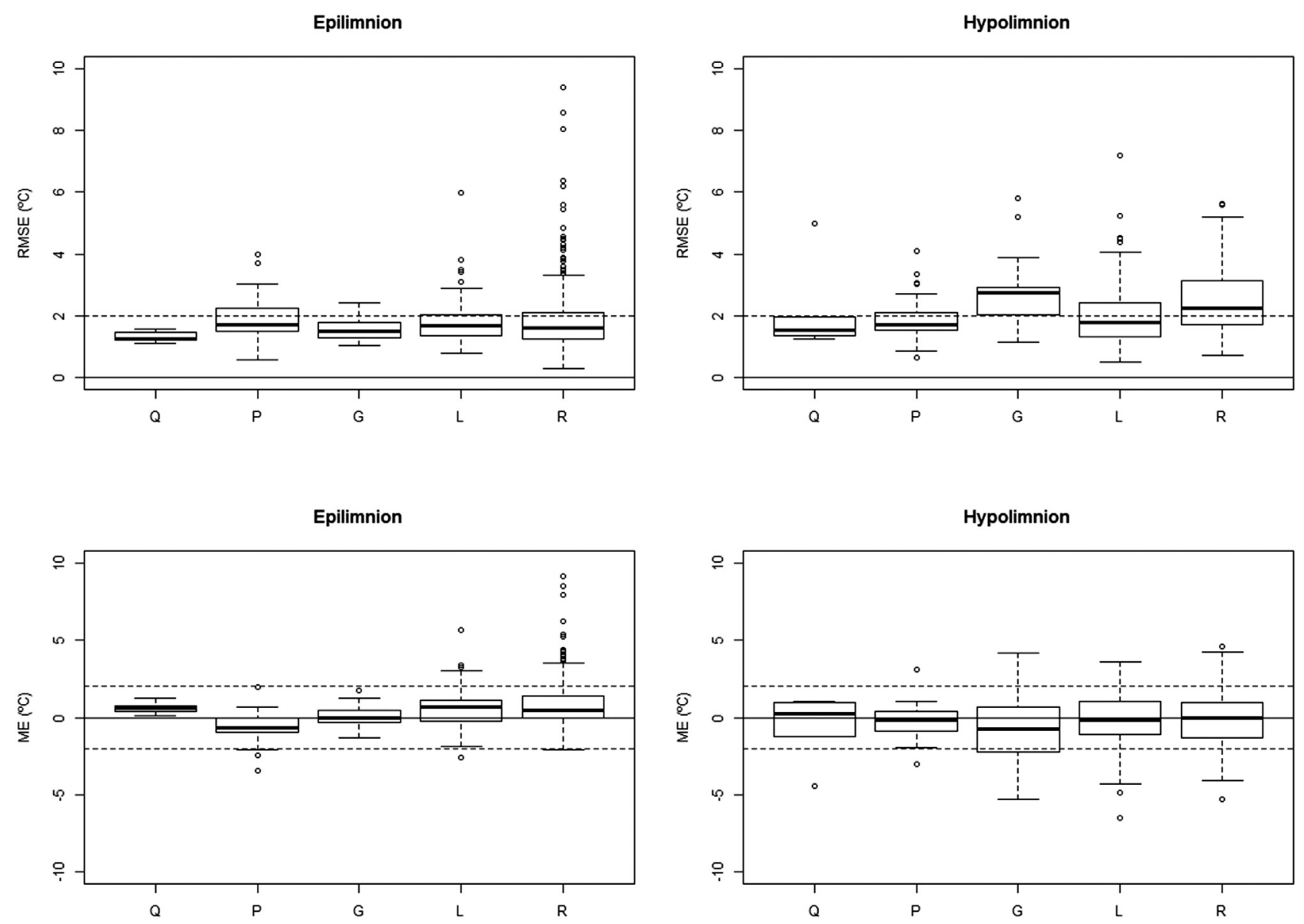

Fig. 10. Root mean square error (RMSE) and mean error (ME) of the simulation of epilimnion and hypolimnion temperatures with the OttossonKettle model by water body type ( $Q: 6$ quarry lakes; $P: 26$ ponds; $G: 27$ gravel pit lakes; $L: 63$ natural lakes; $R: 282$ reservoirs).

were statistical differences between gravel pit lakes and ponds $(p$-value $=0.05)$, between gravel pit lakes and natural lakes $(p$-value $=0.03)$ and between reservoirs and natural lakes $(p$-value $=0.01)$. The median RMSE of hypolimnion simulations was below $2{ }^{\circ} \mathrm{C}$ for all water body types except for gravel pit lakes and reservoirs (Fig. 10 right), which showed higher errors (RMSE $=2.7^{\circ} \mathrm{C}$ for gravel pit lakes, and $\mathrm{RMSE}=2.3^{\circ} \mathrm{C}$ for reservoirs).

The lowest quality simulations of epilimnion temperatures occurred for water bodies (lakes and reservoirs) deeper than $10 \mathrm{~m}$ and for ponds around $1 \mathrm{~m}$ deep (Fig. 11). The lowest quality simulations of hypolimnion temperature occurred for water bodies of depths between $\sim 3 \mathrm{~m}$ and $\sim 30 \mathrm{~m}$. This corresponds to a transition zone between polymictic water bodies and stratified water bodies with hypolimnion at $\sim 4{ }^{\circ} \mathrm{C}$. For deep water bodies $\left(L_{\mathrm{D}}>10-15 \mathrm{~m}\right)$ the quality of hypolimnion temperature simulations was better for lakes than for reservoirs.

\subsection{Summer and winter surface temperatures}

To describe the thermal environment of ectotherms it is necessary to take into account the range of temperature variation (Camacho et al., 2015). In particular, environmental agencies and stakeholders are most interested in high temperatures, which can cause mortality and thermal stress
(Caissie et al., 2001; Davies-Colley et al., 2013). In fact, in France maximum annual water temperature is the main parameter determining the composition of the fish community in lakes (Roubeix et al., 2017). However, low temperatures are important too. Low winter temperatures are important for the recruitment of fish species (McCollum et al., 2003) and can act as thermal barrier against invasive species (Hesselschwerdt and Wantzen, 2018). For these reasons, it is especially important to simulate accurately summer and winter temperatures. The results for these periods by model are shown in the Figure 12. In average the OK model tended to give slightly biased estimates of summer temperatures (median bias of $0.52{ }^{\circ} \mathrm{C}, p$-value $<0.001$ according to the Wilcoxon test), in contrast to FLake, which provided overall unbiased summer temperatures (median bias of $0.15^{\circ} \mathrm{C}, p$-value $=0.15$ ), and air2water, which underestimated summer temperatures by $1.12^{\circ} \mathrm{C}$ ( $p$-value $<0.001)$. In winter, all models showed some kind of bias: FLake showed a median ME of $-2.71^{\circ} \mathrm{C}$ ( $p$-value $<0.001)$; the OK model showed a median ME of $1.37^{\circ} \mathrm{C}(p$-value $<0.001)$; air2water showed a median ME of $-0.73^{\circ} \mathrm{C}(p$-value $<0.001)$. Air2water had the smallest median RMSE for winter temperatures $\left(1.09^{\circ} \mathrm{C}\right)$.

Figure 13 shows the OK model results for summer and winter by water body type. In the summer, the RMSE was 


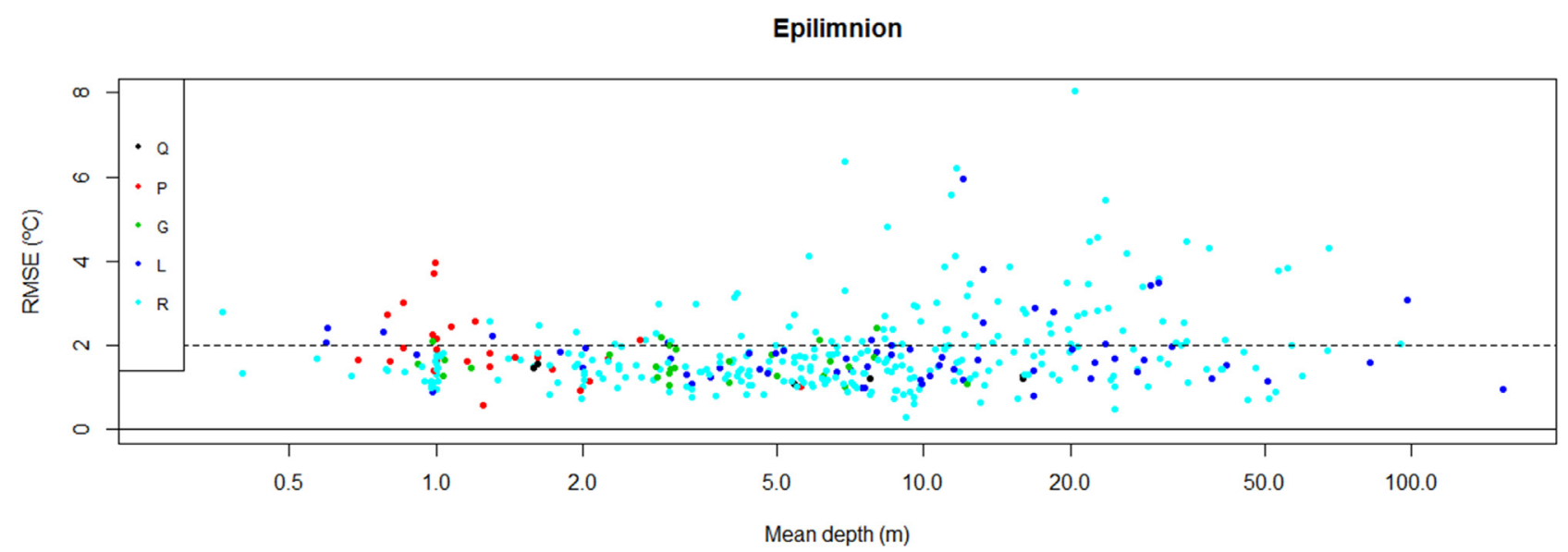

Hypolimnion

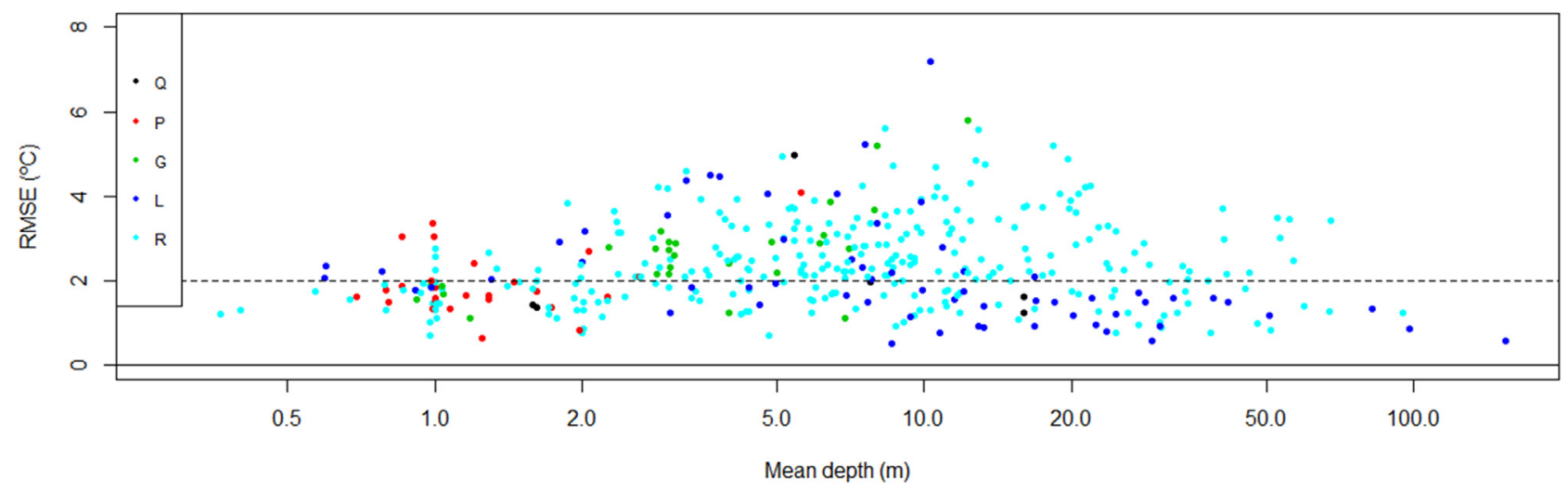

Fig. 11. Root mean square error (RMSE) of the simulation of epilimnion and hypolimnion temperatures with the Ottosson modified model for different water body types ( $Q: 6$ quarry lakes; $P: 26$ ponds; $G: 27$ gravel pit lakes; $L: 63$ natural lakes; $R: 282$ reservoirs).

lowest for ponds (median RMSE $=1.0^{\circ} \mathrm{C}$ ), and was statistically different from RMSE for natural lakes ( $p$-value $=0.007$ according to Conover test) and reservoirs ( $p$-value $=0.008$ according to Conover test). According to the Conover test, there were statistical differences in ME between ponds and quarry lakes $(p$-value $=0.014)$, and between ponds and reservoirs $(p$-value $=0.013)$. ME was mainly positive for quarry lakes (median $\mathrm{ME}=1.48^{\circ} \mathrm{C}, \quad p$-value $=0.03$ ) and reservoirs (median $\mathrm{ME}=0.66^{\circ} \mathrm{C}, p$-value $<0.001$ ) and unbiased for natural lakes (median $\mathrm{ME}=0.31^{\circ} \mathrm{C}, p$-value $=$ 0.18 ), ponds (median $\mathrm{ME}=-0.20^{\circ} \mathrm{C}, p$-value $=0.29$ ) and gravel pit lakes (median $\mathrm{ME}=0.07^{\circ} \mathrm{C}, p$-value $=0.86$ ). In the winter differences between groups were not statistically significant $(p$-value $=0.65$ for $\mathrm{RMSE}, \quad p$-value $=0.15$ for ME, according to the Kruskal-Wallis test). Although some patterns other than those expressed above seem to appear in the figures, the low number of water bodies in some categories and the great variability in the reservoirs and natural lakes groups do not allow to state further conclusions.

Figure 14 shows the ME for epilimnion temperature simulations with the OK model for summer and winter. In the summer there was a positive correlation between ME and mean depth (Kendall's tau $=0.31, p$-value $<0.001$ ) and in the winter there was a negative correlation between these variables
(Kendall's tau $=-0.20, p$-value $=0.001$ ). In the summer the epilimnion temperature of shallow water bodies $\left(L_{\mathrm{D}}<5 \mathrm{~m}\right)$ tended to be underestimated by the $\mathrm{OK}$ model by $0.25^{\circ} \mathrm{C}$ in median ( $p$-value $=0.003$, according to the Wilcoxon test), while in the winter it tended to be overestimated by $1.91^{\circ} \mathrm{C}$ in average ( $p$-value $<0.001$, according to the Wilcoxon test). For water bodies deeper than $5 \mathrm{~m}$, the epilimnion temperatures were overestimated by $1.16^{\circ} \mathrm{C}$ in average in summer ( $p$-value $<0.001$, according to the Wilcoxon test), and by $0.97^{\circ} \mathrm{C}$ in winter $(p$-value $<0.001)$.

\subsection{Evaluation with continuous profiles}

Model performance varied with water body, and the simulated epilimnion or hypolimnion temperatures (Tabs. 5 and 6, Figs. 15 and 16). For the five sites of the French continuous network of lake water temperature (Tab. 2), the air2water model with fitted parameters simulated epilimnion temperatures best in all cases, with negligible ME and RMSE $<1{ }^{\circ} \mathrm{C}$ in most cases. The OK model was second best, except for SCR04, where FLake performed slightly better. In this case, the OK model accurately simulated the temperatures during the warming part of the annual cycle, but FLake simulated better the cooling part of the cycle. Most of the time, 

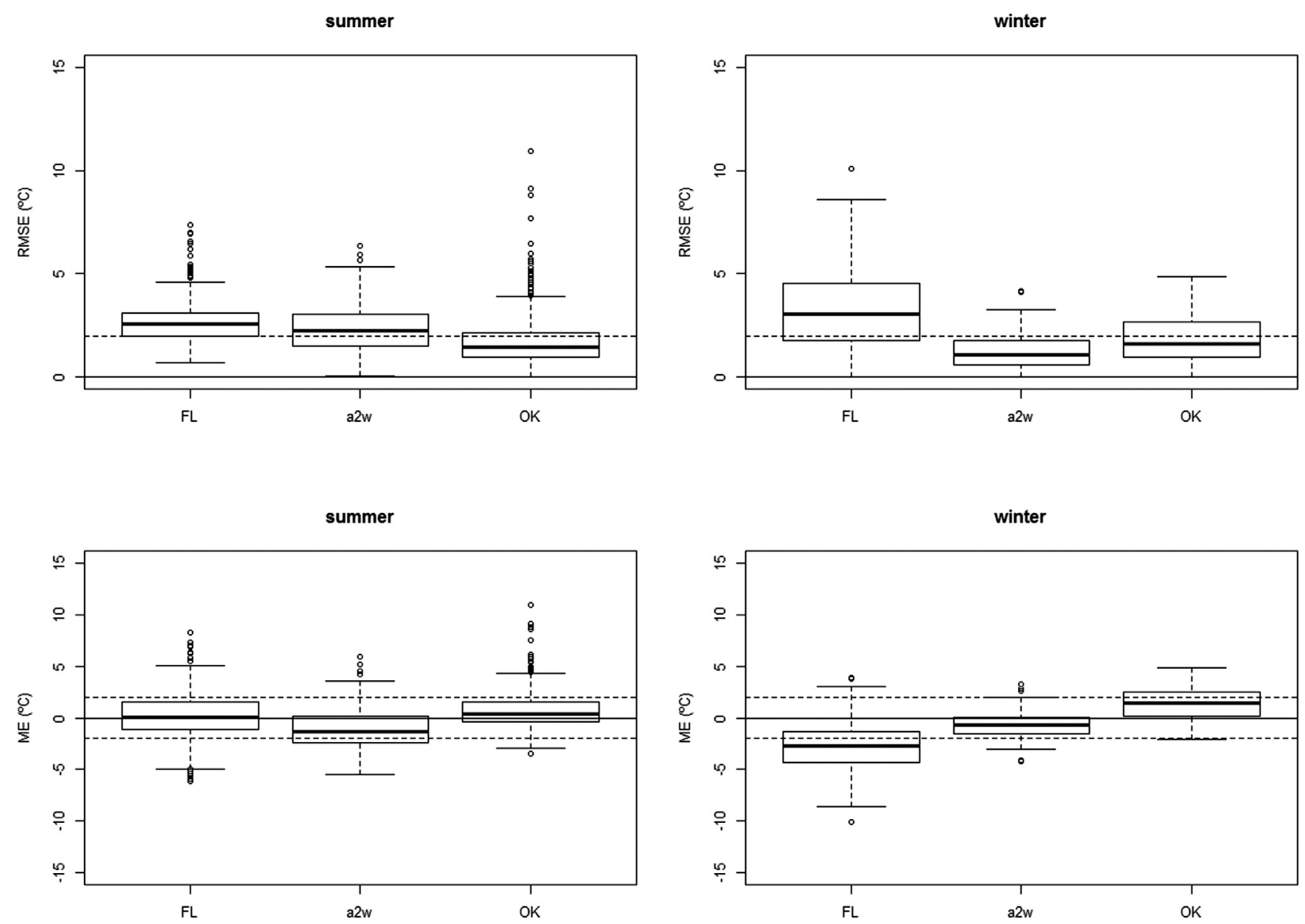

Fig. 12. Root mean square error (RMSE) and mean error (ME) of the simulation of epilimnion summer and winter temperatures for the three tested models (FL: FLake; OK: Ottosson-Kettle model; a2w: 4-parameter air2water).

the air2water model with fitted parameters and the OK model showed similar trajectories following closely the measured temperatures. However, the OK model tended to overestimate temperatures, except in autumn and winter in SCR04 where it tended to underestimate them. In addition, the variability of winter temperatures simulated by the OK model seemed to be too high compared to measurements in several cases (see BIM13, LPC38, PAV63 and SCR04 in Fig. 15).

Hypolimnion temperatures were simulated best by FLake at four out of five sites, the exception being PAV63, where the OK model performed better. However, the correlation between measurements and simulations was better for the OK model, except at LPC38 where it was very similar for both models. In fact, FLake often predicted sharp increases of the hypolimnion temperature at the end of the stratification season, when mixing takes place (see BIM13, PAV63 and SCR04 in Fig. 16), which explains the lower correlation. In addition, the evaluation of the performance of hypolimnion temperature simulations made using profile data and continuous data seemed to produce different results, that is, with profile data the OK model performed better than FLake, while with continuous data FLake seemed to perform better than the OK model. However, this difference was not statistically significant $(p$-value $=1$ for RMSE, $p$-value $=0.81$ for $\mathrm{ME}$, according to the paired Wilcoxon test comparing the performance results for the five water bodies).

\section{Discussion}

\subsection{Parameterization of the OK model}

Although the OK model is not process-based, the values of its parameters reflect the thermal processes taking place. They show geographical and altitudinal gradients, as well as the influence of morphometry. According to equation (21), the MAET (parameter $A$ ) depends on latitude and altitude. Such patterns have been identified of old (Delebecque, 1898; Straškraba and Gnauck, 1985; Hostetler, 1995), but this work identifies more precisely the influence of latitude and altitude in French lakes, with a decrease in MAET of $0.48^{\circ} \mathrm{C}$ for each degree in latitude and a decrease of $4.5^{\circ} \mathrm{C}$ for each kilometre in altitude. The equation (21) also shows that the MAET depended on the surface area of the water body too: the MAET decreased with increasing surface area. This effect is linked to wind effects, that favour mixing (Rueda and Schladow, 2009) and evaporation.

The latitudinal dependence of the MAET found for France is greater than the value of $0.34{ }^{\circ} \mathrm{C}$ per degree in latitude used in the model LAKETEMP of worldwide lake temperature (Straškraba and Gnauck, 1985). The rate of epilimnion temperature decrease with altitude is coherent with estimations of $4.3^{\circ} \mathrm{C} / \mathrm{km}$ for lakes in Papua New Guinea (Vyverman and Sabbe, 1995), but they contrast to average values of $6.9^{\circ} \mathrm{C} / \mathrm{km}$ 

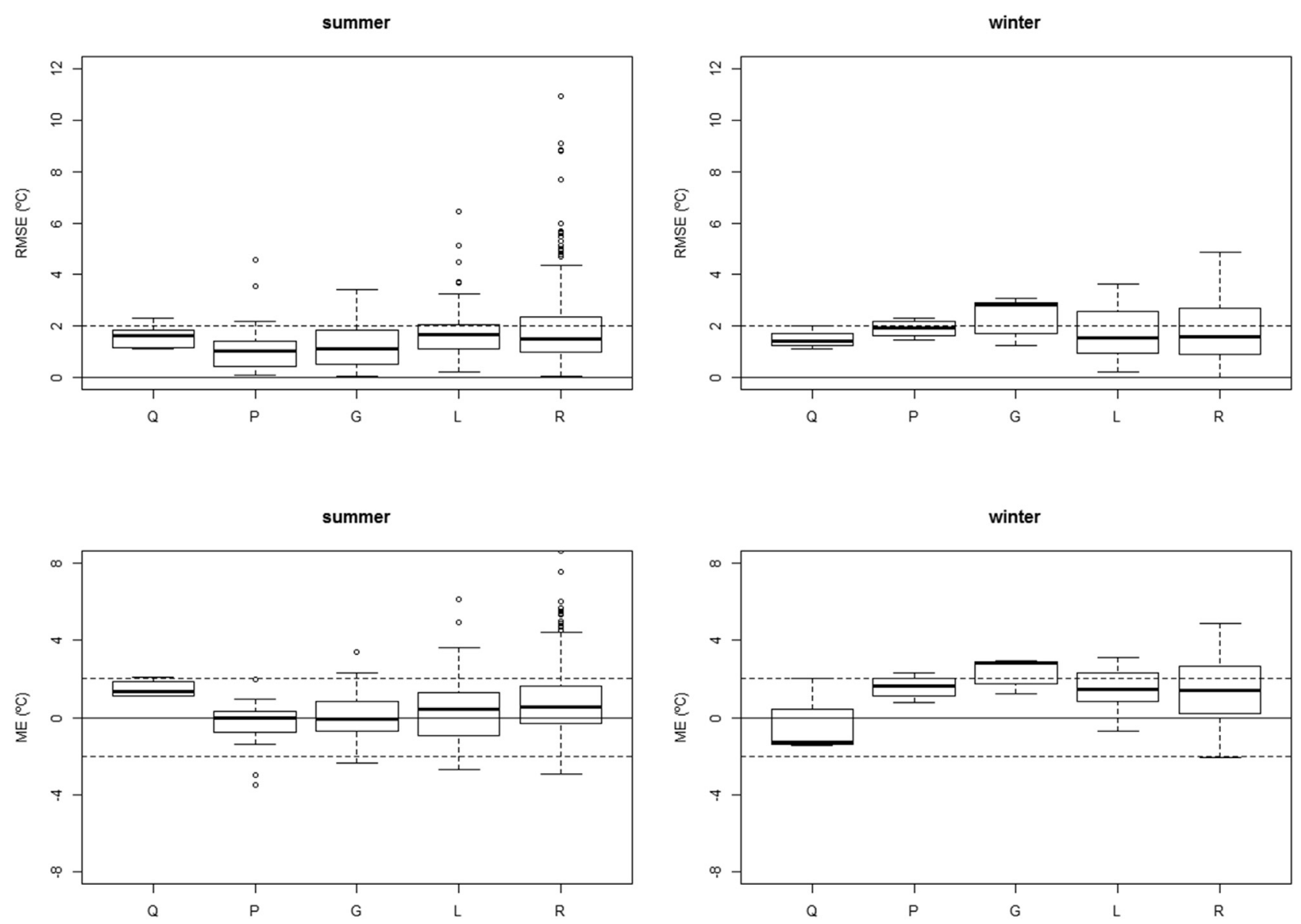

Fig. 13. Root mean square error (RMSE) and mean error (ME) of the simulation of summer and winter epilimnion temperatures with the Ottosson modified model by water body type ( $Q$ : quarry lake; $P$ : pond; $G$ : gravel pit lake; $L$ : natural lake; $R$ : reservoir). In the summer data was available for 6 quarry lakes, 26 ponds, 27 gravel pit lakes, 63 natural lakes and 282 reservoirs; in the winter data was available for 4 quarry lakes, 4 ponds, 5 gravel pit lakes, 17 natural lakes and 89 reservoirs.

found for Swiss lakes below 2000 masl for the months of June to September (Livingstone et al., 2005). The reason for such high lapse rates for Swiss lakes may be the effect of ice and snow in the catchment area (Livingstone et al., 1999). For lakes above 2000 masl Livingstone et al. (2005) also found a change in the lapse rate compared to lower altitude lakes: it was greater from June to August, but it was smaller in September. Although some of our study lakes were above 2000 masl, there were not enough satellite images, or there were not enough measurements in the year, to determine the MAET. Thus, our data does not allow us to confirm whether such a change in lapse rate occurs in French lakes.

The parameter $\alpha$, the smoothing parameter of the air temperature exponential smoothing function, is related to the way the epilimnion responds to meteorological forcing. Greater surface areas tend to decrease smoothing, while greater volumes and depths tend to intensify it, as reflected in equation (23). Given two water bodies of equal volume, the one with a greater surface area has a greater surface of exchange of heat with the atmosphere and responds more steadily to atmospheric conditions. Plus, the greater the volume (and depth) of a water body is, the greater its thermal inertia. In our case, for individually fitted lakes the median value of $\alpha$ was 0.19 , the mean value was 0.22 and the $25 \%$ and
$75 \%$ percentiles were 0.13 and 0.29 , respectively. These values are coherent with the values found by Kettle et al. (2004), with a median value of $\alpha=0.23$, and $25 \%$ and $75 \%$ percentiles of 0.15 and 0.31 . Still, Livingstone et al. (2005) used a constant value of $\alpha=0.33$ for all lakes, since an individually optimized value of $\alpha$ provided only a slight improvement in the performance of simulations.

The parameter $B$ affects the amplitude of the annual water temperature cycle. Kettle et al. (2004) suggest the parameter $B$ is dependent on the mixing depth, so that deep lakes are less sensitive to meteorological forcing. In contrast to their results, in our case the relation between $B$ and depth was linear rather than logarithmic (Tab. 3, Fig. 4), and decreased more slowly with depth. Still, the variation in the individually fitted values was great in comparison to the slope of the linear regression, which resulted in a low correlation coefficient with the simulated values.

The parameter $C$ affects the mean, amplitude and phase of the annual water temperature cycle: an increase in the value of $C$ increases the mean temperature, advances the annual temperature maximum and enlarges the annual amplitude. The parameter $C$ interacts with the other epilimnion temperature parameters $A, \alpha$ and $B$ (Kettle et al., 2004), so that is it difficult to explain the physical meaning of the regression equation used 

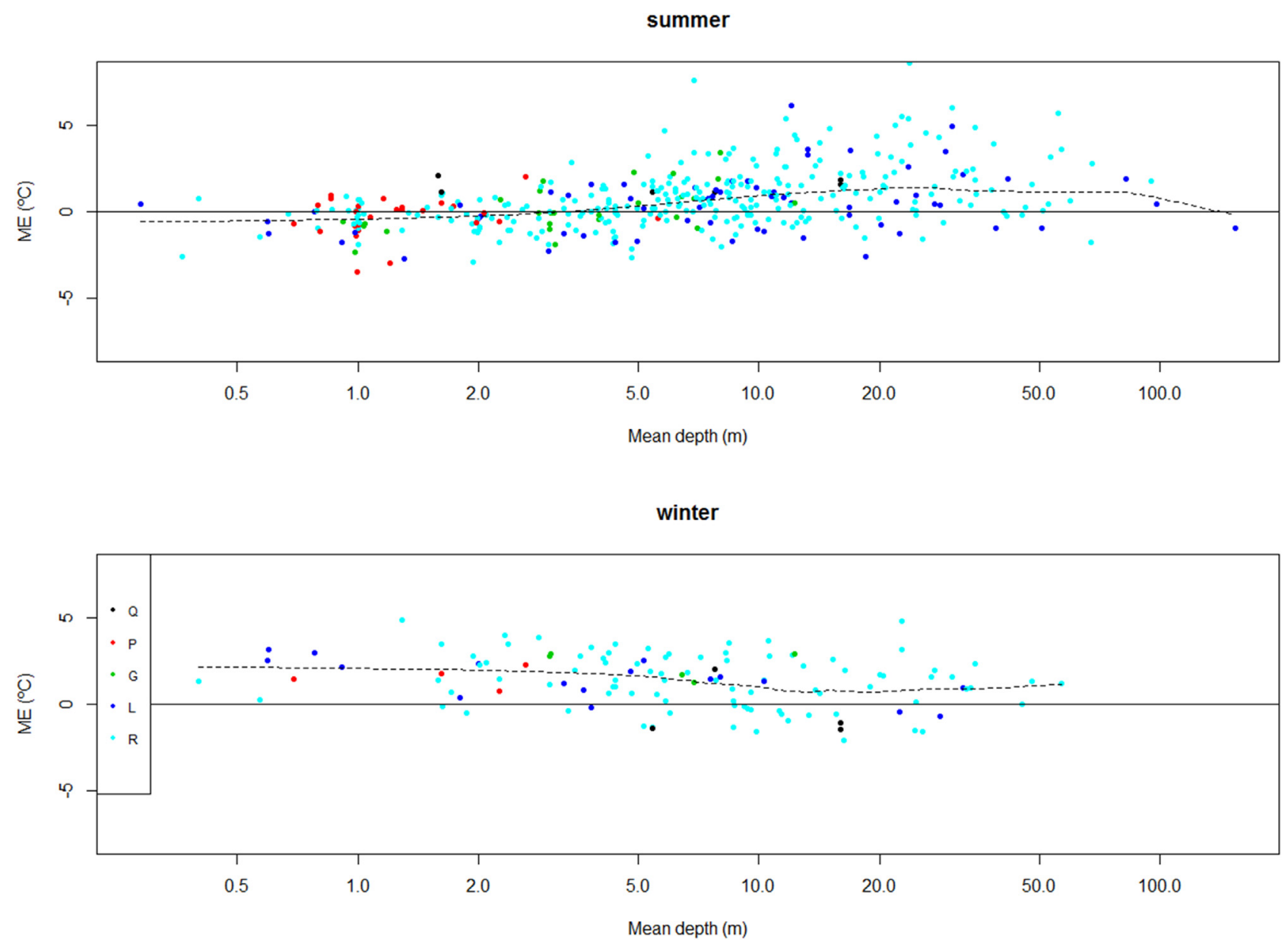

Fig. 14. Mean error (ME) of the simulation of summer and winter epilimnion temperatures with the Ottosson modified model for different water body types ( $Q$ : quarry lake; $P$ : pond; $G$ : gravel pit lake; $L$ : natural lake; $R$ : reservoir) and LOWESS smoothing line over all data points (discontinuous line). In the summer data was available for 6 quarry lakes, 26 ponds, 27 gravel pit lakes, 63 natural lakes and 282 reservoirs; in the winter data was available for 4 quarry lakes, 4 ponds, 5 gravel pit lakes, 17 natural lakes and 89 reservoirs.

Table 5. Root mean square error (RMSE) of epilimnion and hypolimnion temperatures by the three models (FL: FLake, OK: Ottosson-Kettle model, a2w: 4-parameter air2water, a2w fitted: air2water with parameters fitted to the data) at five sites with continuous measurements available.

\begin{tabular}{|c|c|c|c|c|c|c|c|c|}
\hline \multirow[b]{2}{*}{ Water body } & \multicolumn{4}{|c|}{ Epilimnion temperature } & \multicolumn{4}{|c|}{ Hypolimnion temperature } \\
\hline & FL & OK & $a 2 w$ & a2w fitted & $\mathrm{FL}$ & $\mathrm{OK}$ & $a 2 w$ & $\mathrm{a} 2 \mathrm{w}$ fitted \\
\hline AUL13 & 2.60 & 1.41 & 1.57 & 0.94 & 2.79 & 3.00 & - & - \\
\hline BIM13 & 2.05 & 1.74 & 1.93 & 0.89 & 2.69 & 4.30 & - & - \\
\hline LPC38 & 1.73 & 1.66 & 2.75 & 1.27 & 1.59 & 3.77 & - & - \\
\hline PAV63 & 2.96 & 1.51 & 3.34 & 0.99 & 1.62 & 0.85 & - & - \\
\hline SCR04 & 1.30 & 1.46 & 2.29 & 0.58 & 1.41 & 2.57 & - & - \\
\hline
\end{tabular}

to estimate it. This also explains that it can take negative values to compensate for the effect of the other parameters.

In Greenland lakes, Kettle et al. (2004) found higher values of the parameter $C$ (Fig. 5) and lower values of the parameter $B$ (Fig. 4) than those found in this study. Also, their equation (5) applied to our data results in lower values of $\alpha$ than the equation (23) used herein (Fig. 3). These differences may be the reflection of a geographical variation of the thermal processes taking place, which the limited latitudinal variation in our data set (between $41.5^{\circ} \mathrm{N}$ and $50.9^{\circ} \mathrm{N}$ ) does not allow to identify. Still, annual surface temperature ranges are lower in higher latitudes than in medium latitudes (Straškraba and Gnauck, 1985; Green et al., 1987), which is consistent with lower values of the parameter $B$.

As described in the Section 5.2.1, the hypolimnion temperature parameters showed a threshold behaviour, oscillating between two states: (1) polymictic and (2) stratified. The location of the critical point for stratification at $E=\mathbf{0 . 9 5}$ 
J. Prats and P.-A. Danis: Knowl. Manag. Aquat. Ecosyst. 2019, 420, 8

Table 6. Mean error (ME) of epilimnion and hypolimnion temperatures by the three models (FL: FLake, Om: Ottosson modified, a2w: 4-parameter air2water, a2w fitted: air2water with parameters fitted to the data) at five sites with continuous measurements available.

\begin{tabular}{|c|c|c|c|c|c|c|c|c|}
\hline \multirow[b]{2}{*}{ Water body } & \multicolumn{4}{|c|}{ Epilimnion temperature } & \multicolumn{4}{|c|}{ Hypolimnion temperature } \\
\hline & FL & OK & $\mathrm{a} 2 \mathrm{w}$ & a2w fitted & FL & OK & $\mathrm{a} 2 \mathrm{w}$ & a2w fitted \\
\hline AUL13 & -1.99 & 1.05 & 1.00 & -0.02 & -1.12 & -2.67 & - & - \\
\hline BIM13 & 0.58 & 0.42 & -1.48 & -0.00 & -0.89 & -4.03 & - & - \\
\hline LPC38 & -1.23 & 0.47 & -2.25 & -0.00 & -0.12 & -2.28 & - & - \\
\hline PAV63 & -1.26 & 0.28 & -2.38 & -0.05 & 1.09 & 0.57 & - & - \\
\hline SCR04 & 0.39 & -0.49 & -2.13 & -0.12 & 0.53 & 0.80 & - & - \\
\hline
\end{tabular}
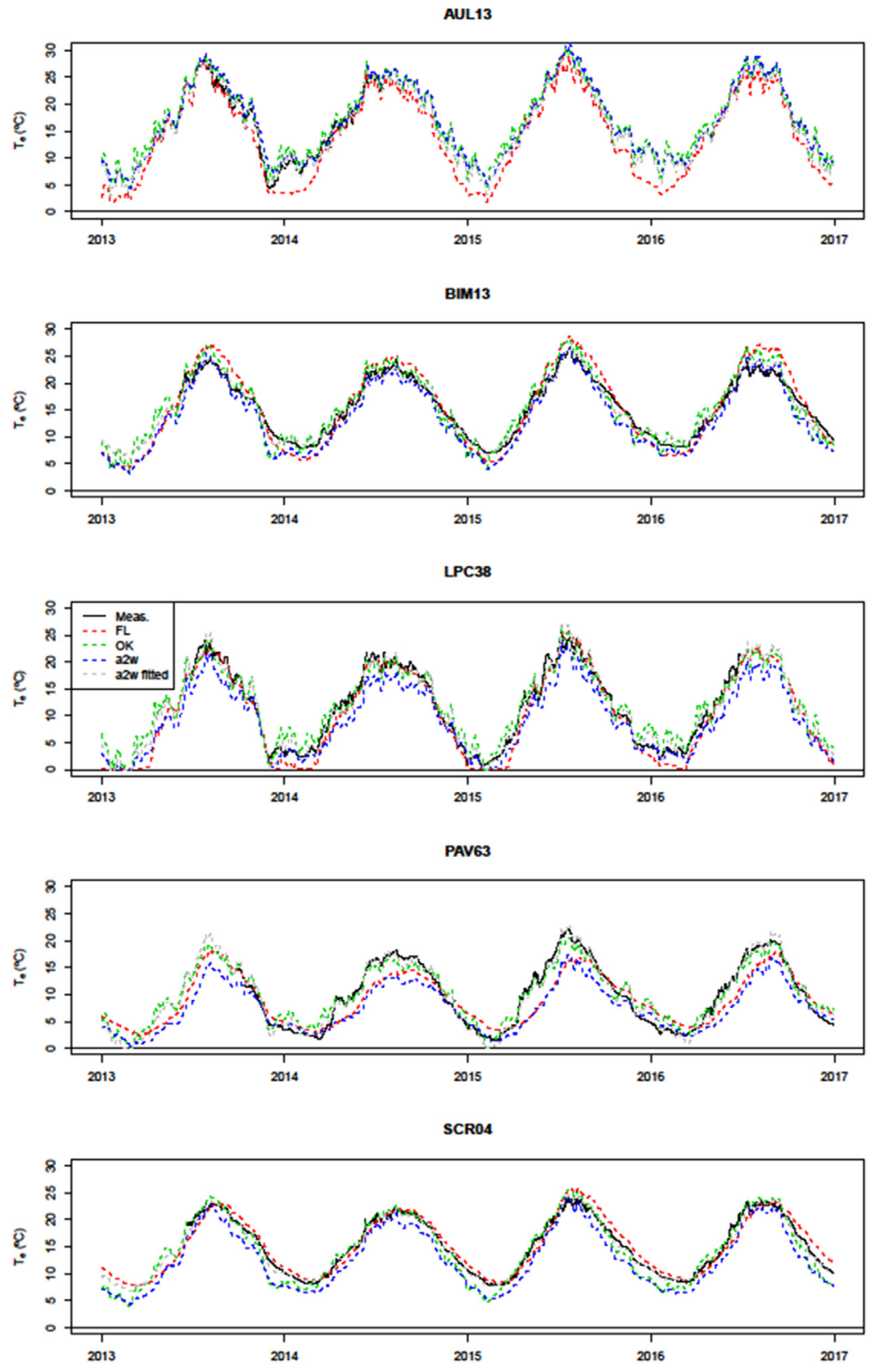

Fig. 15. Epilimnion temperature: continuous measurements and simulations with the three different models (FL: FLake; OK: Ottosson-Kettle model; a2w: 4-parameter air2water, a2w fitted: air2water with fitted parameters) for 2013-2016. 

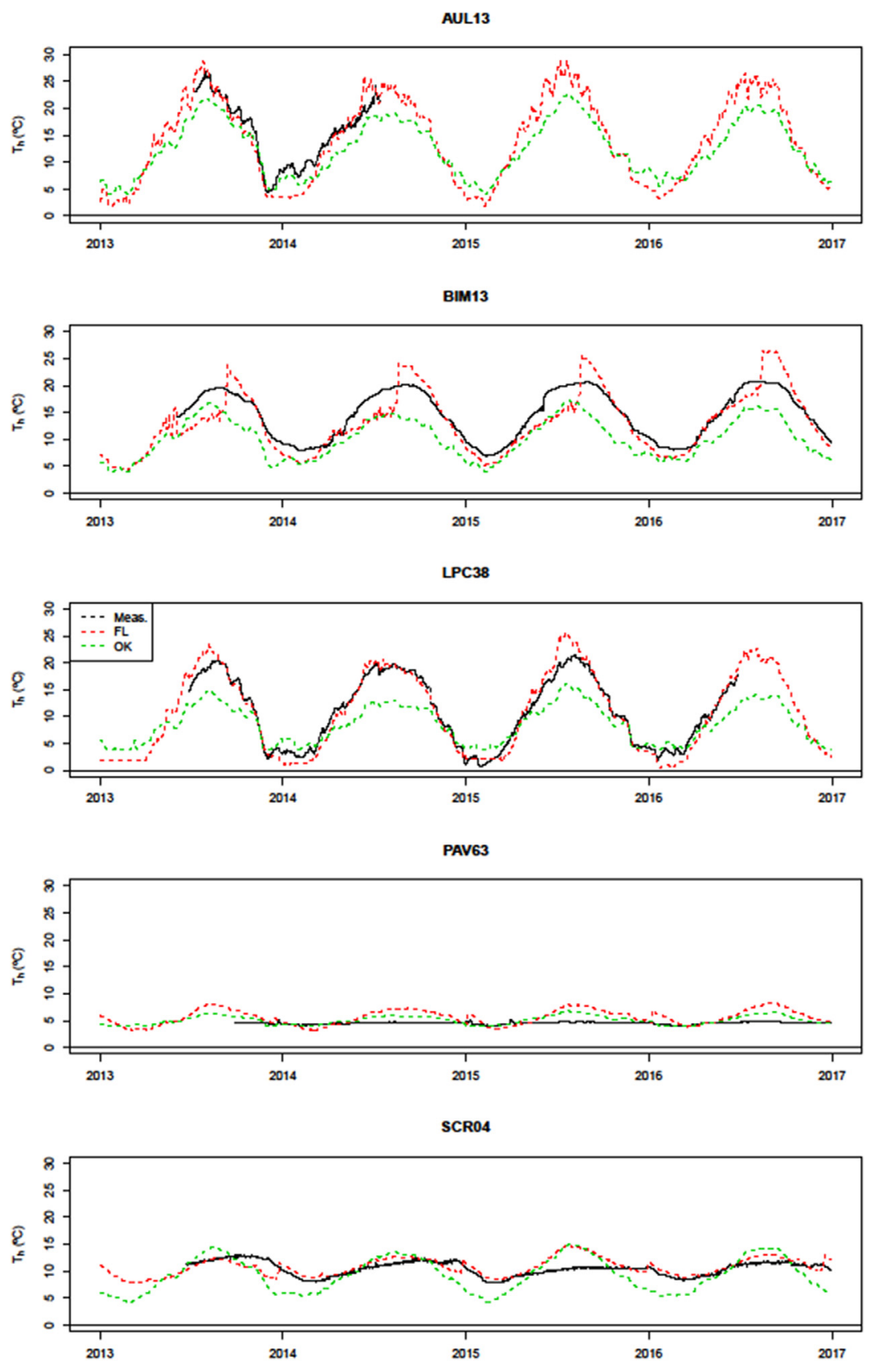

Fig. 16. Hypolimnion temperature: continuous measurements and simulations with the different models (FL: FLake; OK: Ottosson-Kettle model) for 2013-2016.

(Eq. (27)) means water bodies with mean depths below $\sim 2 \mathrm{~m}$ are classified as polymictic, which is consistent with an observed depth limit of $2-8 \mathrm{~m}$ between polymictic and monomictic lakes (Touchart, 2002). In a study of 86 Canadian lakes of $<500$ ha, Snucins and Gunn (2000) found lakes below $5 \mathrm{~m}$ deep did not usually stratify. Other authors propose that the transition between polymictic and stratified lakes occurs at $L_{\mathrm{A}}^{0.25} / L_{\mathrm{Dmax}} \sim 2.5-5.0 \mathrm{~m}^{-0.5}$ (Stefan et al., 1996) and more complex indexes based on physical derivations have been proposed (Gorham and Boyce, 1989; Kirillin and Shatwell, 2016).

\subsection{Model performance}

One of the objectives of this paper is to derive a parameterization for the $\mathrm{OK}$ model that can be applied to French lakes where data for calibration is insufficient and to assess its performance in comparison to two other widely used models. Our results support the good performance of the parameterized $\mathrm{OK}$ model, which performed better than FLake and the parameterized version of air2water. However, FLake used no calibrated values and the calibrated parameters used in the implementation of air2water were a preliminary 
calibration with 14 (mostly large) lakes (Toffolon et al., 2014) that might not be representative of the studied group of French water bodies.

Still, using individually calibrated values improves the quality of the simulations and is preferable when sufficient data is available and the modeller is interested in simulating accurate temperatures rather than understanding general patterns. In fact, when using the individually calibrated values of the parameters for the OK model, the median RMSE of epilimnion temperatures was $1.5^{\circ} \mathrm{C}$, a slight improvement respect to the parameterized version (median $\mathrm{RMSE}=1.7^{\circ} \mathrm{C}$ ). For air2water, the median RMSE of the simulations with the original calibration data was $1.2^{\circ} \mathrm{C}$, for both the 8-parameter version and the 4-parameter version (Toffolon et al., 2014). Also, the air2water simulations with calibrated parameters for the five water bodies with continuous measurements showed a radical improvement in the performance of the model, with RMSE $<1{ }^{\circ} \mathrm{C}$ in most of the cases. In addition, Layden et al. (2016) showed that by tuning some lake properties (lake depth, snow and ice albedo and light extinction coefficient) the bias of FLake epilimnion temperature simulations could be reduced from $\sim 3^{\circ} \mathrm{C}$ to $<1{ }^{\circ} \mathrm{C}$.

The performance of the $\mathrm{OK}$ model was also good in comparison to more complex lake models. The physically based 1D General Lake Model (GLM) was recently tested on a set of 32 lakes worldwide in the framework of the Multi-Lake Comparison Project (Bruce et al., 2018). Under these conditions GLM showed a mean RMSE of $1.62^{\circ} \mathrm{C}$ for epilimnion temperatures and of $1.31{ }^{\circ} \mathrm{C}$ for hypolimnion temperatures. The RMSE for the simulation of hypolimnion temperatures under this test was much lower than the obtained in our study both for FLake of the OK model. However, hypolimnion temperatures are easier to simulate in deep water bodies, where it remains rather constant near $4{ }^{\circ} \mathrm{C}$ throughout the year. And in fact, their set of lakes included only $10 \%$ of lakes with maximum depths below $10 \mathrm{~m}$, compared to about $30 \%$ in our case. A previous application of GLM to 2368 Winsconsin lakes (Read et al., 2014), with a much greater proportion of shallow lakes (median $L_{\text {Dmax }}$ of $6.71 \mathrm{~m}$ ), resulted in an overall RMSE of $1.74{ }^{\circ} \mathrm{C}$ for epilimnion temperatures and of $3.33{ }^{\circ} \mathrm{C}$ for hypolimnion temperatures. In the application of another water quality model, MINLAKE, to a set of 28 Minnesota lakes, the average standard error of temperature simulations was $1.47^{\circ} \mathrm{C}$ (Fang et al., 2012).

Regarding summer temperatures, which are of special interest for managers, they were well simulated by the $\mathrm{OK}$ model, with a median RMSE of $1.4^{\circ} \mathrm{C}$. Winter temperatures were simulated slightly less well, with a median bias of $1.4^{\circ} \mathrm{C}$ and a median RMSE of $1.6^{\circ} \mathrm{C}$. This different performance between seasons may be due to the unequal distribution of satellite measurements throughout the year. Because satellite surface temperature measurements depend on the absence of clouds, more measurements were available in the spring, summer and autumn than in winter, so that winter measurements had less weight in the fitting of the parameters for individual water bodies. In addition, the values of the epilimnion temperature parameters $\alpha, B$ and $C$ should be expected to vary throughout the year, in stratified water bodies. In summer, it is mostly the epilimnion that responds to meteorological forcing while in the winter all the water column is affected (Boehrer and Schultze, 2008). Recent results by
Schmidt et al. (2018) support this hypothesis. They found water temperature variability at the monthly time scale at Müggelsee increased from winter to summer, and decreased from summer to winter. In addition, they found differences in water temperature variability between spring and autumn that were not due to differences in air temperature variability or mean water temperature, but to the vertical thermal structure and associated mixing processes. Woolway et al. (2014) also found an increase in the diel surface temperature range at the onset of the stratification. Surface water temperature is more sensitive to air temperature variations in the warming phase of the annual cycle than in the cooling phase (McCombie, 1959; Livingstone and Lotter, 1998).

In the winter reservoirs showed a much greater variability in bias than the other types of water body (Fig. 13). In some cases the winter bias could amount to several degrees (Figs. 13 and 14). The reservoir bias was negatively correlated with surface area (Kendall's tau $=-0.38, p$-value $<0.001$ ). However, in the winter the number of reservoirs with available profile measurements (89 reservoirs) was much greater than for the rest of water bodies (4 quarry lakes, 4 ponds, 5 gravel pit lakes and 17 natural lakes), which could explain the greater variability in bias for reservoirs. Another possible explanation is that the water level in reservoirs varies much more than in other types of water body, affecting their thermal behaviour, while the water level is considered constant in the simulations.

The quality of the hypolimnion temperature simulations made with the OK model was worse than that of epilimnion temperature simulations. In fact, there was a high uncertainty in the parameterisation of the parameters $\beta$ and $E$. In particular, the value of $E$ for stratifying not-natural lakes depends greatly on the outlet depth and water level management plan. However, since the objective was to derive a parameterisation based on morphometry and geographical variables, this fact has not been taken into account, causing higher errors in the simulations of hypolimnion temperatures for this type of water bodies (Fig. 10). In those cases, and especially for deep reservoirs, it would be advisable to use individually fitted values of $E$. If at least summer temperature profile data is available, the equation (26) may be used to estimate $E$.

In addition, we propose here a constant critical value for stratification of $E=0.95$. Still, the value of $E$ is related to several variables (Prats and Danis, 2015), including wind speed and Secchi disk depth, and a more appropriate course of action might be the derivation of a criterion based on the use of stability indexes that take into account the effect of wind such as Schmidt stability or the Wedderburn number (Imberger and Patterson, 1989). A first attempt to include such effects was done by Bouchez (2010) by proposing a mixing criterion that depended on the Wedderburn number. This has not been done here to keep the model as simple as possible and to limit the requirements of input data.

\subsection{Limitations of the proposed modelling approach}

The simulation of water temperature is a complex issue that depends on the exchanges of heat (short wave and long wave radiation, evaporation and conduction), matter (water vapour, inflows and outflows) and mechanical energy (wind stress) (Imberger and Patterson, 1989). The simulation of water 
temperatures also depends on the internal mixing and stratification processes driven by the exchanges of energy and influenced by chemical and thermal gradients and by biological activity (Imberger and Patterson, 1989; Boehrer and Schultze, 2008). Process-based lake ecosystem models are designed to take into account all these factors and are the best option when the system is well known and we are interested in studying its behaviour out of the range of historical observations (Robson, 2014). However, they require lots of data to calibrate the model (Mooij et al., 2010; Robson, 2014).

For many water bodies detailed data (flow, water level, bathymetry, etc.) is not available and a simpler approach is necessary. The approach proposed here requires only air temperature as forcing data and a few morphological and geographical characteristics to determine the value of the model parameters. While the results show a good performance compared to other models, its limitations should be acknowledged. First, given the statistical nature of the parameterization, the model cannot be applied out of the range of conditions for which it has been derived (Robson, 2014). In particular, simulations to assess the effect of climate change should be interpreted with caution, not only because of the statistical nature of the model, but also because it does not take into account all the factors that may affect the thermal behaviour. Climate change can affect other meteorological variables in addition to air temperature. For example, the warming of surface water in Lake Zurich has been attributed to the combined effect of increased air temperature and solar radiation (Schmid and Köster, 2016).

In addition, the model does not take into account the effect of inflow and outflow. For example, under climate change an increase of snowmelt from glaciers can cause the cooling of lakes (Pizarro et al., 2016). Thermal effluents from power plants or the variation in the inflow volume can also affect the thermal behaviour of lakes (Kirillin et al., 2013; Valerio et al., 2015). These effects cannot be simulated by the models used in this paper, and are expected to be more important in water bodies with short residence times (Rimmer et al., 2011).

Other factors not taken into account by the OK model are water transparency and wind speed. One-dimensional models are sensitive to the value of water transparency, especially for clear waters (light extinction coefficient $<0.5 \mathrm{~m}^{-1}$ ) (HendersonSellers, 1988; Heiskanen et al., 2015). In our data set $23 \%$ of water bodies had light extinction coefficients below $0.5 \mathrm{~m}^{-1}$, and transparency was correlated to depth, with deeper water bodies being clearer (Roubeix and Danis, 2016). Since wind speed affects evaporation and the mixing regime, the lake surface temperature is very sensitive to it (Henderson-Sellers, 1988). A part of the effect of wind is taken into account through the epilimnion parameters depending on surface area, the surface over which the wind can act. However, this is a general effect and transient effects due to high wind speeds that can produce the mixing of the water column are not taken into account. The inclusion of transparency and wind effects in future versions of the model would probably improve its performance further.

\section{Conclusions}

We present herein a two-layer water temperature model based in the modification of the model of Ottosson and
Abrahamsson (1998) by replacing the epilimnion temperature formulation by that proposed by Kettle et al. (2004) and by proposing a new parameterisation of the model parameters adapted to metropolitan France. The new parameterisation is dependent on the geographical (latitude and altitude) and morphological characteristics (depth, surface and volume) of the water bodies. And it includes a different parameterisation of the parameter $E$, which determines the vertical temperature gradient, for natural and not-natural lakes. We believe the proposed parameterisation should be applicable to water bodies with similar characteristics to those in the study set and not affected by upstream glaciers. The performance of the model was good (median RMSE of $1.7^{\circ} \mathrm{C}$ for the epilimnion and of 2.3 for the hypolimnion), in particular for the simulation of epilimnion summer temperatures (median RMSE of $1.4^{\circ} \mathrm{C}$ ). Simulated epilimnion winter temperatures, though, tended to be overestimated by $0.5^{\circ} \mathrm{C}$ in median. The simulation of hypolimnion temperatures was best for shallow water bodies and for deep natural lakes. For the simulation of hypolimnion temperatures for deep reservoirs, and given the fact that the model does not take into account the outlet depth and water level management, it would be preferable to use a value of $E$ based on actual measurements of the vertical temperature profile. Because of the simplicity of the model, which only requires air temperature as forcing data and the geographical and morphological characteristics of the studied water bodies, and because of its good performance, the modified Ottosson's model is a good choice for managers for the simulation of lake water temperatures, and in particular of summer water temperatures.

\section{Author contribution statement}

P.-A. Danis obtained funding and designed the study, and managed the continuous monitoring of temperature in French lakes. J. Prats developed the model code and performed the simulations. P.-A. Danis tested the model code and user guide. J. Prats prepared the manuscript with contributions from P.-A. Danis.

\section{Conflict of interests}

The authors declare that they have no conflict of interest.

Acknowledgements. This study was funded by the Onema (French National Office for Water and Aquatic Environments now called French Agency for Biodiversity, AFB) action $61 \mathrm{~B}$. The authors thank the members of the AFBIrstea consortium Nathalie Reynaud, Thierry Point and Thierry Tormos for their help with lake and satellite data. The authors are grateful to the AFB agents Jean-Claude Raymond and William Sremski and the Irstea agent Tiphaine Peroux who contributed to the continuous monitoring of temperature, to the French Water Basin Agencies and their partners who contributed to lake temperature acquisition in RCS and RCO, and to Météo-France for providing SAFRAN data. The authors thank Renato Henriques da Silva, Diane Von-Gunten, Marco Toffolon and Sebastiano Piccolroaz for their useful comments. 


\section{References}

Allan MG, Hamilton DP, Trolle D, Muraoka K, McBride C. 2016. Spatial heterogeneity in geothermally-influenced lakes derived from atmospherically corrected Landsat thermal imagery and three-dimensional hydrodynamic modelling. Int J Appl Earth Obs 50: $106-116$

Barton K. 2018. MuMIn: Multi-Model Inference. R package version 1.42.1.

Bernhardt J, Engelhardt C, Kirillin G, Matschullat J. 2012. Lake ice phenology in Berlin-Brandenburg from 1947-2007: observations and model hindcasts. Clim Change 112: 791-817.

Boehrer B, Schultze M. 2008. Stratification of lakes. Rev Geophys 46: L16405.

Bouchez C. 2010. Modélisation des températures de surface et de fond des plans d'eau. École de Mines de Paris \& École Nationale du Génie Rural des Eaux et des Forêts, Université Pierre et Marie Curie, 49.

Bruce LC, Frassl MA, Arhonditsis GB, Gal G, Hamilton DP, Hanson PC, Hetherington AL, Melack JM, Read JS, Rinke K, Rigosi A, Trolle D, Winslow L, Adrian R, Ayala AI, Bocaniov SA, Boehrer B, Boon C, Brookes JD, Bueche T, Busch BD, Copetti D, Cortés A, de Eyto E, Elliott JA, Gallina N, Gilboa Y, Guyennon N, Huang L, Kerimoglu O, Lenters JD, MacIntyre S, Makler-Pick V, McBride CG, Moreira S, Özkundakci D, Pilotti M, Rueda FJ, Rusak JA, Samal NR, Schmid M, Shatwell T, Snorthheim C, Soulignac F, Valerio G, van der Linden L, Vetter M, Vinçon-Leite B, Wang J, Weber M, Wickramaratne C, Woolway RI, Yao H, Hipsey MR. 2018. A multi-lake comparative analysis of the General Lake Model (GLM): Stress-testing across a global observatory network. Environ Modell Softw 102: 274-291.

Butcher J, Nover D, Johnson T, Clark C. 2015. Sensitivity of lake thermal and mixing dynamics to climate change. Clim Change 129: 295-305.

Byrd RH, Lu P, Nocedal J, Zhu C. 1995. A limited memory algorithm for bound constrained optimization. SIAM J Sci Comput 16: 1190 1208.

Caissie D, El-Jabi N, Satish MG. 2001. Modelling of maximum daily water temperatures in a small stream using air temperatures. J Hydrol 251: 14-28.

Camacho A, Trefaut Rodrigues M, Navas C. 2015. Extreme operative temperatures are better descriptors of the thermal environment than mean temperatures. $J$ Therm Biol 49-50: 106-111.

Conover WJ, Iman RL. 1979. On multiple-comparisons procedures. NM, USA: Los Alamos Scientific Lab., pp. 1-17.

Czernecki B, Ptak M. 2018. The impact of global warming on lake surface water temperature in Poland - the application of empiricalstatistical downscaling, 1971-2100. J Limnol 77: 330-348.

Danis P-A, von Grafenstein U, Masson-Delmotte V, Planton S, Gerdeaux D, Moisselin JM. 2004. Vulnerability of two European lakes in response to future climatic changes. Geophys Res Lett 31: L21507.

Daufresne M, Boet P. 2007. Climate change impacts on structure and diversity of fish communities in rivers. Glob Change Biol 13: 2467-2478.

Daufresne M, Lengfellner K, Sommer U. 2009. Global warming benefits the small in aquatic ecosystems. Proc Natl Acad Sci 106: 12788-12793.

Davies-Colley R, Franklin P, Wilcock B, Clearwater S, Hickey C. 2013. National Objectives Framework - Temperature, dissolved oxygen \& $\mathrm{pH}$ proposed thresholds for discussion. Hamilton, New Zealand: NIWA, 83 pp.
Delebecque A. 1898. Les lacs français. Paris, France: Typographie Chamerot et Renouard, $436 \mathrm{pp}$.

Dodson R, Marks D. 1997. Daily air temperature interpolated at high spatial resolution over a large mountainous region. Clim Res 8: 1-20.

Donlon CJ, Minnett PJ, Gentemann C, Nightingale TJ, Barton IJ, Ward B, Murray MJ. 2002. Toward improved validation of satellite sea surface skin temperature measurements for climate research. J Clim 15: 353-369.

Dörnhöfer K, Oppelt N. 2016. Remote sensing for lake research and monitoring - Recent advances. Ecol Indic 64: 105-122.

Falconer IR. 1999. An overview of problems caused by toxic bluegreen algae (cyanobacteria) in drinking and recreational water. Environ Toxicol 14: 5-12.

Fang X, Alam SR, Stefan HG, Jiang L, Jacobson PC, Pereira DL. 2012. Simulations of water quality and oxythermal cisco habitat in Minnesota lakes under past and future climate scenarios. Water Qual Res J Can 47: 375-388.

Fang X, Stefan HG. 2009. Simulations of climate effects on water temperature, dissolved oxygen, and ice and snow covers in lakes of the contiguous United States under past and future climate scenarios. Limnol Oceanogr 54: 2359-2370.

Foley B, Jones ID, Maberly SC, Rippey B. 2012. Long-term changes in oxygen depletion in a small temperate lake: effects of climate change and eutrophication. Freshwater Biol 57: 278-289.

Gao L, Bernhardt M, Schulz K. 2012. Elevation correction of ERAInterim temperature data in complex terrain. Hydrol Earth Syst Sci 16: 4661-4673.

Gorham E, Boyce FM. 1989. Influence of lake surface area and depth upon thermal stratification and the depth of the summer thermocline. J Great Lakes Res 15: 233-245.

Goward S, Arvidson T, Williams D, Faundeen J, Irons J, Franks S. 2006. Historical record of Landsat global coverage. Photogramm Eng Remote Sensing 72: 1155-1169.

Green JD, Viner AB, Lowe DJ. 1987. The effect of climate on lake mixing patterns and temperatures. In: Viner $A B$, ed. Inland Waters of New Zealand. Wellington: New Zealand Department of Scientific and Industrial Research, pp. 65-95.

Håkanson L. 1996. A new, simple, general technique to predict seasonal variability of river discharge and lake temperature for lake ecosystem models. Ecol Model 88: 157-181.

Håkanson L, Boulion VV. 2001. A practical approach to predict the duration of the growing season for European lakes. Ecol Model 140: 235-245.

Han B-P, Armengol J, Garcia JC, Comerma M, Roura M, Dolz J, Straskraba M. 2000. The thermal structure of Sau Reservoir (NE: Spain): a simulation approach. Ecol Model 125: 109-122.

Handcock RN, Torgersen CE, Cherkauer KA, Gillespie AR, Tockner K, Faux RN, Tan J. 2012. Thermal infrared remote sensing of water temperature in riverine landscapes. In: Carbonneau PE, Piégay $\mathrm{H}$, eds. Fluvial Remote Sensing for Science and Management. NJ: Wiley, pp. 85-113.

Heiskanen JJ, Mammarella I, Ojala A, Stepanenko V, Erkkilä K-M, Miettinen H, Sandström H, Eugster W, Leppäranta M, Järvinen H, Vesala T, Nordbo A. 2015. Effects of water clarity on lake stratification and lake-atmosphere heat exchange. $J$ Geophys Res Atmos 120: 7412-7428.

Henderson-Sellers B. 1988. Sensitivity of thermal stratification models to changing boundary conditions. Appl Math Model 12: 31-43.

Hesselschwerdt J, Wantzen KM. 2018. Global warming may lower thermal barriers against invasive species in freshwater ecosystems - A study from Lake Constance. Sci Total Environ 645: $44-50$. 
Hostetler SW. 1995. Hydrological and thermal response of lakes to climate: description and modeling. In: Lerman A, Imboden DM, Gat JR, eds. Physics and Chemistry of Lakes. Berlin, Heidelberg: Springer, pp. 63-82.

Huang Y, Liu H, Hinkel K, Yu B, Beck R, Wu J. 2017. Analysis of thermal structure of arctic lakes at local and regional scales using in situ and multidate Landsat-8 data. Water Resour Res 53: 9642 9658.

Ibelings BW, Backer LC, Kardinaal WEA, Chorus I. 2014. Current approaches to cyanotoxin risk assessment and risk management around the globe. Harmful Algae 40: 63-74.

Imberger J, Patterson JC. 1989. Physical limnology. Adv Appl Mech 27: $303-475$.

Janssen ABG, Arhonditsis GB, Beusen A, Bolding K, Bruce L, Bruggeman J, Couture RM, Downing AS, Alex Elliott J, Frassl MA, Gal G, Gerla DJ, Hipsey MR, Hu F, Ives SC, Janse JH, Jeppesen E, Jöhnk KD, Kneis D,Kong X, Kuiper JJ, Lehmann MK, Lemmen C, Özkundakci D, Petzoldt T, Rinke K, Robson BJ, Sachse R, Schep SA, Schmid M, Scholten H, Teurlincx S, Trolle D, Troost TA, Van Dam AA, Van Gerven LPA, Weijerman M, Wells SA, Mooij WM. 2015. Exploring, exploiting and evolving diversity of aquatic ecosystem models: a community perspective. Aquat Ecol 49: 513-548.

Jöhnk KD, Huisman J, Sharples J, Sommeijer B, Visser PM, Stroom JM. 2008. Summer heatwaves promote blooms of harmful cyanobacteria. Glob Change Biol 14: 495-512.

Kawai Y, Wada A. 2007. Diurnal sea surface temperature variation and its impact on the atmosphere and ocean: A review. J Oceanogr 63: 721-744.

Kettle H, Thompson R, Anderson NJ, Livingstone DM. 2004. Empirical modeling of summer lake surface temperatures in southwest Greenland. Limnol Oceanogr 49: 271-282.

Kirillin G, Shatwell T. 2016. Generalized scaling of seasonal thermal stratification in lakes. Earth-Sci Rev 161: 179-190.

Kirillin G, Shatwell T, Kasprzak P. 2013. Consequences of thermal pollution from a nuclear plant on lake temperature and mixing regime. J Hydrol 496: 47-56.

Kraemer BM, Anneville O, Chandra S, Dix M, Kuusisto E, Livingstone DM, Rimmer A, Schladow SG, Silow E, Sitoki LM, Tamatamah R, Vadeboncoeur Y, McIntyre PB. 2015. Morphometry and average temperature affect lake stratification responses to climate change. Geophys Res Lett 42: 4981-4988.

Kruskal WH, Wallis WA. 1952. Use of ranks in one-criterion variance analysis. J Am Stat Assoc 47: 583-621.

Layden A, MacCallum SN, Merchant CJ. 2016. Determining lake surface water temperatures worldwide using a tuned onedimensional lake model (FLake, v1). Geosci Model Dev 9: 2167-2189.

Layden A, Merchant C, MacCallum S. 2015. Global climatology of surface water temperatures of large lakes by remote sensing. Int $J$ Climatol. 35: 4464-4479.

Le Moigne P, Colin J, Decharme B. 2016. Impact of lake surface temperatures simulated by the FLake scheme in the CNRM-CM5 climate model. Tellus A 68: 31274.

Leeper TJ. 2018. tabulizer: Bindings for Tabula PDF Table Extractor Library, R package version 0.2. 2 .

Ling F, Foody G, Du H, Ban X, Li X, Zhang Y, Du Y. 2017. Monitoring thermal pollution in rivers downstream of dams with Landsat ETM+ thermal infrared images. Remote Sens (Basel) 9: 1175.

Livingstone DM, Lotter AF. 1998. The relationship between air and water temperatures in lakes of the Swiss Plateau: a case study with pal\sgmaelig;olimnological implications. J Paleolimnol 19: 181198.

Livingstone DM, Lotter AF, Kettle H. 2005. Altitude-dependent differences in the primary physical response of mountain lakes to climatic forcing. Limnol Oceanogr 50: 1313-1325.

Livingstone DM, Lotter AF, Walkery IR. 1999. The decrease in summer surface water temperature with altitude in Swiss Alpine Lakes: a comparison with air temperature lapse rates. Arct Antarct Alp Res 31: 341-352.

MacKay MD, Neale PJ, Arp CD, Domis LNDS, Fang X, Gal G, Jöhnk KD, Kirillin G, Lenters JD, Litchman E, MacIntyre S, Marsh P, Melack J, Mooij WM, Peeters F, Quesada A, Schladow SG, Schmid M, Spence C, Stokesr SL. 2009. Modeling lakes and reservoirs in the climate system. Limnol Oceanogr 54: 2315-2329.

Martí-Cardona B, Arbat-Bofill M, Prats-Rodríguez J, Pipia L. 2016. Thermal remote sensing for reservoir modelling and management. In: Ouwehand L, ed. Living Planet Symposium 2016. Prague, Czech Republic: ESA Communications, 4 pp.

Marti-Cardona B, Steissberg TE, Schladow SG, Hook SJ. 2008. Relating fish kills to upwellings and wind patterns in the Salton Sea. Hydrobiologia 604: 85-95.

McCollum AB, Bunnell DB, Stein RA. 2003. Cold, northern winters: the importance of temperature to overwinter mortality of age- 0 white crappies. Trans Am Fish Soc 132: 977-987.

McCombie AM. 1959. Some relations between air temperatures and the surface water temperatures of lakes. Limnol Oceanogr 4: 252-258.

McKinney W. 2010. Data structures for statistical computing in python, in 9th Python in Science Conference (SciPy 2010), Austin, Texas, pp. 51-56.

Mironov DV. 2008. Parameterization of lakes in numerical weather prediction. Description of a lake model. In: Milelli M, ed. COSMO Technical Reports, Offenbach am Main.

Mokhov II, Akperov MG. 2006. Tropospheric lapse rate and its relation to surface temperature from reanalysis data. Izv Atmos Ocean Phys 42: 430-438.

Mooij W, Trolle D, Jeppesen E, Arhonditsis G, Belolipetsky PV, Chitamwebwa DBR, Degermendzhy AG, DeAngelis DL, De Senerpont Domis LN, Downing AS, Elliott JA, Fragoso CR Jr, Gaedke U, Genova SN, Gulati RD, Håkanson L, Hamilton DP, Hipsey MR, 't Hoen J, Hülsmann S, Los FH, Makler-Pick V, Petzoldt T, Prokopkin IG, Rinke K, Schep SA, Tominaga K, Van Dam AA, Van Nes EH, Wells SA, Janse JH. 2010. Challenges and opportunities for integrating lake ecosystem modelling approaches. Aquat Ecol 44: 633-667.

O'Reilly CM, Sharma S, Gray DK, Hampton SE, Read JS, Rowley RJ, Schneider P, Lenters JD, McIntyre PB, Kraemer BM, Weyhenmeyer GA, Straile D, Dong B, Adrian R, Allan MG, Anneville O, Arvola L, Austin J, Bailey JL, Baron JS, Brookes JD, de Eyto E, Dokulil MT, Hamilton DP, Havens K, Hetherington AL, Higgins SN, Hook S, Izmest'eva LR, Joehnk KD, Kangur K, Kasprzak P, Kumagai M, Kuusisto E, Leshkevich G, Livingstone DM, MacIntyre S, May L, Melack JM, Mueller-Navarra DC, Naumenko M, Noges P, Noges T, North RP, Plisnier P-D, Rigosi A, Rimmer A, Rogora M, Rudstam LG, Rusak JA, Salmaso N, Samal NR, Schindler DE, Schladow SG, Schmid M, Schmidt SR, Silow E, Soylu ME, Teubner K, Verburg P, Voutilainen A, Watkinson A, Williamson CE, Zhang G. 2015. Rapid and highly variable warming of lake surface waters around the globe. Geophys Res Lett 42: 10773-10781.

Ottosson F, Abrahamsson O. 1998. Presentation and analysis of a model simulating epilimnetic and hypolimnetic temperatures in lakes. Ecol Model 110: 233-253. 
Paerl HW, Huisman J. 2008. Blooms like it hot. Science 320: 57-58.

Piccolroaz S. 2016. Prediction of lake surface temperature using the air2water model: guidelines, challenges, and future perspectives. Adv Oceanogr Limnol 7: 36-50.

Piccolroaz S, Healey NC, Lenters JD, Schladow SG, Hook SJ, Sahoo GB, Toffolon M. 2018. On the predictability of lake surface temperature using air temperature in a changing climate: A case study for Lake Tahoe (U.S.A.). Limnol Oceanogr 63: 243-261.

Piccolroaz S, Toffolon M, Majone B. 2013. A simple lumped model to convert air temperature into surface water temperature in lakes. Hydrol Earth Syst Sci 17: 3323-3338.

Piccolroaz S, Toffolon M, Majone B. 2015. The role of stratification on lakes' thermal response: The case of Lake Superior. Water Resour Res 51: 7878-7894.

Pizarro J, Vergara PM, Cerda S, Briones D. 2016. Cooling and eutrophication of southern Chilean lakes. Sci Total Environ 541: 683-691.

Pohlert T. 2018. PMCMRplus: Calculate Pairwise Multiple Comparisons of Mean Rank Sums Extended, R package version 1.3.0.

Prats J, Danis P-A. 2015. Optimisation du réseau national de suivi pérenne in situ de la température des plans d'eau : apport de la modélisation et des données satellitaires, Rapport Final. Aix-enProvence: Onema, $94 \mathrm{pp}$.

Prats J, Reynaud N, Rebière D, Peroux T, Tormos T, Danis PA. 2018a. LakeSST: Lake skin surface temperature in French inland water bodies for 1999-2016 from Landsat archives. Earth Syst Sci Data 10: $727-743$

Prats J, Salençon M-J, Gant M, Danis P-A. 2018b. Simulation of the hydrodynamic behaviour of a Mediterranean reservoir under different climate change and management scenarios. J Limnol 77: $62-81$.

Quintana-Seguí P, Le Moigne P, Durand Y, Martin E, Habets F, Baillon M, Canellas C, Franchisteguy L, Morel S. 2008. Analysis of near-surface atmospheric variables: validation of the SAFRAN analysis over France. J Appl Meteorol 47: 92-107.

R Core Team. 2015. R: A language and environment for statistical computing, R Foundation for Statistical Computing, Vienna, Austria.

Raftery AE. 1995. Bayesian model selection in social research. Sociol Methodol 25: 111-163.

Read JS, Winslow LA, Hansen GJA, Van Den Hoek J, Hanson PC, Bruce LC, Markfort CD. 2014. Simulating 2368 temperate lakes reveals weak coherence in stratification phenology. Ecol Model 291: $142-150$.

Riffler M, Lieberherr G, Wunderle S. 2015. Lake surface water temperatures of European Alpine lakes (1989-2013) based on the Advanced Very High Resolution Radiometer (AVHRR) $1 \mathrm{~km}$ data set. Earth Syst Sci Data 7: 1-17.

Rimmer A, Gal G, Opher T, Lechinsky Y, Yacobi YZ. 2011. Mechanisms of long-term variations in the thermal structure of a warm lake. Limnol Oceanogr 56: 974-988.

Robson BJ. 2014. When do aquatic systems models provide useful predictions, what is changing, and what is next? Environ Modell Softw 61: 287-296.

Rolland C. 2003. Spatial and seasonal variations of air temperature lapse rates in Alpine regions. J Clim 16: 1032-1046.

Roubeix V, Danis P-A. 2016. Relations entre paramètres physicochimiques des plans d'eau et accupation du bassin versant. Estimation des Conditions de Référence. Aix-en-Provence: Onema, $26 \mathrm{pp}$.

Roubeix V, Daufresne M, Argillier C, Dublon J, Maire A, Nicolas D, Raymond J-C, Danis P-A. 2017. Physico-chemical thresholds in the distribution of fish species among French lakes. Knowl Manag Aquat Ecosyst 41.

Rueda F, Schladow G. 2009. Mixing and stratification in lakes of varying horizontal length scales: Scaling arguments and energy partitioning. Limnol Oceanogr 54: 2003-2017.

Sahoo GB, Forrest AL, Schladow SG, Reuter JE, Coats R, Dettinger M. 2015. Climate change impacts on lake thermal dynamics and ecosystem vulnerabilities. Limnol Oceanogr 61: 496-507.

Salençon M-J. 1997. Study of the thermal dynamics of two dammed lakes (Pareloup and Rochebut, France), using the EOLE model. Ecol Model 104: 15-38.

Schaeffer BA, Iiames J, Dwyer J, Urquhart E, Salls W, Rover J, Seegers B. 2018. An initial validation of Landsat 5 and 7 derived surface water temperature for U.S. lakes, reservoirs, and estuaries. Int J Remote Sens 1-17.

Schluessel P, Emery WJ, Grassl H, Mammen T. 1990. On the bulkskin temperature difference and its impact on satellite remote sensing of sea surface temperature. $J$ Geophys Res Oceans 95: 13341-13356.

Schmid M, Köster O. 2016. Excess warming of a Central European lake driven by solar brightening. Water Resour Res 52: 81038116.

Schmidt SR, Gerten D, Hintze T, Lischeid G, Livingstone DM, Adrian R. 2018. Temporal and spatial scales of water temperature variability as an indicator for mixing in a polymictic lake. Inland Waters 8: 82-95.

Schneider P, Hook SJ. 2010. Space observations of inland water bodies show rapid surface warming since 1985. Geophys Res Lett 37: L22405.

Schneider P, Hook SJ, Radocinski RG, Corlett GK, Hulley GC, Schladow SG, Steissberg TE. 2009. Satellite observations indicate rapid warming trend for lakes in California and Nevada. Geophys Res Lett 36: L22402.

Snucins E, Gunn J. 2000. Interannual variation in the thermal structure of clear and colored lakes. Limnol Oceanogr 45: 1639-1646.

Stefan HG, Hondzo M, Fang X, Eaton JG, McCormick JH. 1996. Simulated long term temperature and dissolved oxygen characteristics of lakes in the north-central United States and associated fish habitat limits. Limnol Oceanogr 41: 1124-1135.

Straškraba M, Gnauck A. 1985. Freshwater Ecosystems: Modelling and Simulation. Amsterdam: Elsevier, 309 pp.

Subin ZM, Riley WJ, Mironov D. 2012. An improved lake model for climate simulations: Model structure, evaluation, and sensitivity analyses in CESM1. J Adv Model Earth Syst 4: M02001.

Toffolon M, Piccolroaz S, Majone B, Soja A-M, Peeters F, Schmid M, Wüest A. 2014. Prediction of surface temperature in lakes with different morphology using air temperature. Limnol Oceanogr 59: 2185-2202.

Tolnai M, Nagy JG, Bakó G. 2016. Spatiotemporal distribution of Landsat imagery of Europe using cloud cover-weighted metadata. $J$ Maps 12: 1084-1088.

Touchart L. 2002. Limnologie physique et dynamique. Paris: L'Harmattan, 396 pp.

Trolle D, Hamilton DP, Pilditch CA, Duggan IC, Jeppesen E. 2011. Predicting the effects of climate change on trophic status of three morphologically varying lakes: Implications for lake restoration and management. Environ Modell Softw 26: 354-370.

Valerio G, Pilotti M, Barontini S, Leoni B. 2015. Sensitivity of the multiannual thermal dynamics of a deep pre-alpine lake to climatic change. Hydrol Process 29: 767-779.

van der Walt S, Colbert SC, Varoquaux G. 2011. The NumPy Array: A structure for efficient numerical computation. Comput Sci Eng 13: $22-30$. 
Venables WN, Ripley BD. 2002. Modern applied statistics with S, 4th ed. New York: Springer.

Vidal J-P, Martin E, Franchistéguy L, Baillon M, Soubeyroux J-M. 2010. A 50-year high-resolution atmospheric reanalysis over France with the Safran system. Int J Climatol 30: 1627-1644.

Vyverman W, Sabbe K. 1995. Diatom-temperature transfer functions based on the altitudinal zonation of diatom assemblages in Papua New Guinea: a possible tool in the reconstruction of regional palaeoclimatic changes. J Paleolimnol 13: 65-77.

Wan W, Li H, Xie H, Hong Y, Long D, Zhao L, Han Z, Cui Y, Liu B, Wang C, Yang W. 2017. A comprehensive data set of lake surface water temperature over the Tibetan Plateau derived from MODIS LST products 2001-2015. Sci Data 4: 170095.

Webb BW, Hannah DM, Moore RD, Brown LE, Nobilis F. 2008. Recent advances in stream and river temperature research. Hydrol Process 22: 902-918.

Wickham H. 2017. tidyverse: Easily Install and Load the 'Tidyverse', $\mathrm{R}$ package version 1.2.1.

Wilcoxon F. 1945. Individual comparisons by ranking methods. Biometrics Bull 1: 80-83.

Wilson RC, Hook SJ, Schneider P, Schladow SG. 2013. Skin and bulk temperature difference at Lake Tahoe: A case study on lake skin effect. J Geophys Res Atmos 118: 10332 310346.

Woolway RI, Dokulil MT, Marszelewski W, Schmid M, Bouffard D, Merchant CJ. 2017. Warming of Central European lakes and their response to the 1980s climate regime shift. Clim Change 142: $505-520$.

Woolway RI, Maberly SC, Jones ID, Feuchtmayr H. 2014. A novel method for estimating the onset of thermal stratification in lakes from surface water measurements. Water Resour Res 50: 5131-5140.

Woolway RI, Merchant CJ. 2017. Amplified surface temperature response of cold, deep lakes to inter-annual air temperature variability. Sci Rep 7: 4130.

Woolway RI, Merchant CJ. 2018. Intralake heterogeneity of thermal responses to climate change: a study of large Northern Hemisphere lakes. J Geophys Res Atmos 123: 3087-3098.

Wulder MA, White JC, Loveland TR, Woodcock CE, Belward AS, Cohen WB, Fosnight EA, Shaw J, Masek JG, Roy DP. 2016. The global Landsat archive: Status, consolidation, and direction. Remote Sens Environ 185: 271-283.

Xiao C, Li P, Feng Z, Wu X. 2018. Spatio-temporal differences in cloud cover of Landsat-8 OLI observations across China during 2013-2016. J Geogr Sci 28: 429-444.

Cite this article as: Prats J, Danis P-A. 2019. An epilimnion and hypolimnion temperature model based on air temperature and lake characteristics. Knowl. Manag. Aquat. Ecosyst., 420, 8 